\title{
A topologia do Ser e a geopolítica do conhecimento. Modernidade, império e colonialidade
}

The Topology of Being and the Geopolitics of Knowledge. Modernity, Empire, Coloniality

La typologie de l'Être et la géopolitique de la connaissance. Modernité, empire et colonialité

Nelson Maldonado-Torres

Tradutor. Inês Martins Ferreira

\section{OpenEdition}

1 Journals

Edição electrónica

URL: https://journals.openedition.org/rccs/695

DOI: $10.4000 /$ rccs.695

ISSN: $2182-7435$

Editora

Centro de Estudos Sociais da Universidade de Coimbra

\section{Edição impressa}

Data de publição: 1 março 2008

Paginação: 71-114

ISSN: 0254-1106

\section{Refêrencia eletrónica}

Nelson Maldonado-Torres, «A topologia do Ser e a geopolítica do conhecimento. Modernidade, império e colonialidade», Revista Crítica de Ciências Sociais [Online], 80 | 2008, publicado a 01 outubro 2012, consultado a 10 fevereiro 2023. URL: http://journals.openedition.org/rccs/695 ; DOI: https:// doi.org/10.4000/rccs.695

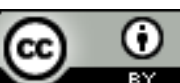

Creative Commons - Atribuição 4.0 Internacional - CC BY 4.0 https://creativecommons.org/licenses/by/4.0/ 


\title{
A topologia do Ser e a geopolítica do conhecimento. Modernidade, império e colonialidade'
}

\begin{abstract}
O ensaio examina a articulação entre raça e espaço na obra de vários pensadores europeus. Centrando-se no projecto de Martin Heidegger de procurar no Ocidente as raízes, denuncia a cumplicidade desse projecto com uma visão cartográfica imperial que cria e separa as cidades dos deuses e as cidades dos danados. O autor identifica concepções análogas noutros pensadores ocidentais, sobretudo em Levinas, Negri, Žižeck, Habermas e Derrida. Ao projecto da busca das raízes, com os seus pressupostos racistas, ele opõe uma visão crítica, inspirada em Fanon, que sublinha o carácter constitutivo da colonialidade e da danação para o projecto da modernidade europeia. $\mathrm{O}$ autor conclui com um apelo a uma diversalidade radical e uma geopolítica do conhecimento descolonial.
\end{abstract}

Até hoje, a fundamentação ontológica tem considerado o Centro como ponto de chegada e de partida. O 'Ser' tem sido, na verdade, o Centro. O 'Pensamento’ tem sido um Pensamento Central. No Centro se encontraram ambos. Fora do Centro, encontra-se o ente, o contingente e o subdesenvolvido; aquilo que só passou a ser reconhecido através do Centro.

\footnotetext{
${ }^{1}$ Em 29 de Março de 2003, apresentei no Encontro Anual da Associação de Estudos Latino-americanos, no Texas, uma versão anterior deste artigo, com o título "Império y colonialidad del ser”. Gostaria de agradecer aos membros do Grupo de Ética Dialógica e Cosmopolitismo Crítico da Universidade de Duke por me terem propiciado um contexto óptimo para testar ideias alternativas do pensamento político radical. Também quero agradecer a Eduardo Mendieta pelos comentários que fez à segunda versão do artigo e pelas recomendações fundamentais no sentido de um posterior alargamento. Gostaria de dedicar o artigo ao grupo de jovens filósofos que, há 30 anos, expuseram, de forma explícita, algumas das ideias que aqui aparecem, respeitantes ao lugar do Ser e do conhecimento. Foram eles Osvaldo Ardíles, Hugo Assmann, Mario Casalla, Horacio Cerutti, Carlos Cullen, Julio de Zan, Enrique Dussel, Aníbal Fornari, Daniel Guillot, António Kinen, Rodolfo Kusch, Diego Pró, Agustín de la Riega, Arturo Roig e Juan Carlos Scannone. Veja-se, a propósito, a colectânea de Ardíles et al., 1973. Esta obra formula críticas originais e propõe alternativas à geopolítica racista do conhecimento e à topologia do Ser, que serão alvo de uma investigação crítica no decorrer do presente artigo. O facto de a obra destes autores ter permanecido desconhecida durante tanto tempo é, de algum modo, a demonstração cabal de como é problemática a geopolítica.
} 
Na sua globalidade, a metafísica impôs uma fundamentação filosófica que passa pelo Centro. A teoria do conhecimento, em todas as suas formas, impôs e continua a impor um Centro Esclarecido. A ética, por sua vez, impõe um Centro através do qual os valores se fazem valer. (Agustín T. de la Riega, apud Ardíles et al., 1973: 216)

\section{Introdução}

Tornou-se uma verdade corriqueira reconhecer que a teoria social sofreu, de um modo genérico, uma viragem espacial comparável à viragem linguística sofrida pela filosofia ocidental. No campo da filosofia também estão a emergir, gradualmente, reflexões em torno do o modo como as ideias sobre a espacialidade modelaram o pensamento filosófico. Durante demasiado tempo, a disciplina da filosofia agiu como se o lugar geopolítico e as ideias referentes ao espaço não passassem de características contingentes do raciocínio filosófico. Evitando, e bem, o reducionismo das determinações geográficas, os filósofos têm tido tendência para considerar o espaço como algo demasiado simplista para ser filosoficamente relevante ${ }^{2}$. De facto, exigem outras razões relevantes para explicar a alergia ao espaço enquanto factor filosófico provido de significado. Há questões referentes ao espaço e às relações geopolíticas que enfraquecem a ideia de um sujeito epistémico neutro, cujas reflexões não são mais do que a resposta aos constrangimentos desse domínio desprovido de espaço que é o universal. Tais questões também põem a descoberto as formas como os filósofos e os professores de filosofia tendem a afirmar as suas raízes numa região espiritual invariavelmente descrita em termos geopolíticos: a Europa. ${ }^{3}$

\footnotetext{
${ }^{2}$ É claro que existem excepções. Talvez a mais óbvia delas seja Hegel, que combinou a temporalidade e a espacialidade na sua explicação do Espírito. É certo que esse Espírito atingiu um clímax na Europa, tendo na América um horizonte futuro (Hegel, 1991). Para uma análise crítica da perspectiva de Hegel acerca da América, ver Casalla, 1992. Para uma explicação alternativa da história mundial oferecida a partir de um ponto de vista "americano", ver Dussel, 1995.

${ }^{3}$ Existem outras modalidades desta realidade. Munido de uma aguda percepção do firme vínculo da disciplina da filosofia à Europa enquanto lugar epistémico, um grupo de jovens filósofos latino-americanos reuniu-se na Argentina na década de 70 do século XX, para debater a relevância do espaço na filosofia e a possibilidade de firmar a reflexão filosófica na América Latina, e não na Europa (ver Nota 1). Num gesto semelhante, em finais da década de 80 alguns filósofos dos Estados Unidos voltaram-se para o pragmatismo como forma de expressar uma filosofia norte-americana. Não obstante os dois projectos partilharem com a filosofia europeia uma especial tendência para buscar raízes não destituídas de problemas, o grupo latino-americano tem revelado uma tendência para ser mais cosmopolita do que o dos Estados Unidos - o que se torna especialmente evidente na obra de Enrique Dussel. O grupo latino-americano também foi mais crítico em relação ao liberalismo do que o seu equivalente do Norte. Reflecti sobre alguns destes aspectos em 'Envisioning Postcolonial Philosophies in the Americas: the cases of pragmatism and Latin América liberation
} 
A ausência de reflexões sobre a geopolítica e a espacialidade na produção de conhecimento vai a par com a falta de reflexão crítica quanto ao empenhamento da filosofia e dos filósofos ocidentais com a Europa enquanto local epistémico privilegiado.

Embora a introdução da espacialidade como factor significativo na compreensão da filosofia seja um importante avanço para a disciplina, pode ser um passo limitado se promover a reafirmação de um novo sujeito epistémico neutro, capaz, por si só, de cartografar o mundo e estabelecer associações entre pensamento e espaço. Isto constitui um risco não apenas para a filosofia, mas também para a teoria social. A ideia não é substituir a suposta neutralidade do filósofo pela imagem igualmente mítica do cartógrafo científico neutro. A introdução da espacialidade enquanto factor significativo na compreensão da filosofia e na produção da teoria social pode vir a ser o novo locus da ideia de um observador ou observadora distanciado(a) que só é capaz de examinar as intrincadas relações entre conhecimento e ideias de espaço porque, no fundo, se encontra para lá dessas relações. É minha conviç̧ão que este tipo de crença na imparcialidade tende, em última análise, a reproduzir uma cegueira, não a respeito do espaço enquanto tal, mas a respeito dos modos não-europeus de pensar e da produção e reprodução da relação colonial/imperial, ou daquilo a que, na esteira da obra do sociólogo peruano Aníbal Quijano, gostaria de designar por colonialidade.

Este artigo concerne ao que denomino por esquecimento da colonialidade por parte tanto da filosofia ocidental como da teoria social contemporânea. De facto, neste contexto só posso oferecer breves análises, desejavelmente suficientes para clarificar quer as minhas críticas relativamente às tendências modernas e contemporâneas da filosofia e da teoria social, quer as minhas sugestões sobre como ultrapassar tais limitações. Na primeira secção do artigo, procedo a uma análise crítica de pensadores influentes da aludida viragem linguística. Centro-me na relação entre a ontologia de Martin Heidegger e a ética metafísica de Emmanuel Lévinas. A minha intenção é demonstrar que se, por um lado, a ontologia heideggeriana e a ética de Lévinas deram uma base sólida à viragem linguística e forneceram meios engenhosos de ultrapassar os limites da ideia ocidental de Homem, por outro, as suas filosofias permaneceram cúmplices de formações espaciais de cariz imperial. As filosofias de um e outro encontram-se marcadas pelo

thought' ("Para uma consideração das filosofias pós-coloniais nas Américas: os casos do pragmatismo e do pensamento da libertação latino-americano"), apresentado na Sessão Plenária da Sociedade para o Avanço da Filosofia Americana, em Denver, Colorado, em 15 de Março de 2003. Algumas dessas ideias encontram-se em Maldonado-Torres, no prelo. 
esquecimento da colonialidade. Na segunda secção, apresento um apanhado teórico da colonialidade, relacionando-a com o conceito de modernidade. Aí estabeleço uma distinção entre esta perspectiva crítica e as teorias críticas que concebem o global como uma rede pós-imperialista de relações, nomeadamente a obra Império de Michael Hardt e Antonio Negri. Na terceira e última secções, proponho uma alternativa à política de identidade ocidental tal como se encontra expressa no projecto da busca de raízes no Ocidente. Em vez de legitimar a busca de raízes europeias e norte-americanas e a respectiva ligação com um ponto de vista pretensamente universal, irei defender uma noção de diversalidade radical. A diversalidade radical é uma crítica das raízes que põe a claro não só a colonialidade mas também o potencial epistémico das epistemas não-europeus.

\section{Entre Atenas e Jerusalém: Heidegger, Lévinas e a busca de raízes}

A obra de Martin Heidegger ocupa um lugar central na lista de filósofos cujo trabalho influenciou a criação e propagação da perspectiva comummente conhecida como viragem linguística, especialmente nas suas variantes hermenêutica e desconstrucionista. Heidegger começou por atingir notoriedade internacional quando mudou as bases da filosofia, deslocando-as da epistemologia para uma forma de reflexão ontológica que oferecia novos modos de pensar o sujeito, a linguagem e a historicidade (Heidegger, 1996a). Para ele, a questão do significado do Ser representava o resgate de um ponto de partida radical caído em esquecimento devido à tradição da metafísica ocidental. Este ponto de partida fornecia os meios para responder à crise da modernidade, pois propunha uma posição filosófica indicadora de modos alternativos de ser e de agir. Heidegger não estava a pensar especificamente na ética quando considerou modos de ser alternativos que desafiavam os parâmetros da modernidade. Os seus escritos procuraram, sim, formular posições do sujeito não inspiradas no primado do sujeito nem no modelo de ser humano que é dominante na modernidade, isto é, o modelo do Homem.

A chave para escapar aos problemáticos efeitos da metafísica e à concepção moderna de homem que, segundo Heidegger, sustentavam o ideal da vida moderna em termos de avanço tecnológico, residia em deslocar a reflexão filosófica das questões epistemológicas para as ontológicas. O que não significa que Heidegger não tivesse nada a ver com a epistemologia; em vez de propor a epistemologia como filosofia primeira, explorou as questões epistemológicas em termos do horizonte de questionamento aberto pela questão do significado do Ser. Embora os primeiros esforços de Heidegger neste sentido tenham conferido uma importância central à antropologia, a 
sua crítica da epistemologia e da ideia de Homem - o sujeito da epistemologia europeia moderna - levou-o a passar de uma perspectiva que via a existência humana como uma abertura ao Ser, para a própria linguagem e para a linguagem enquanto lugar da reflexão ontológica. Depois da viragem - a chamada Kebre - heideggeriana, a viragem ontológica acabou por representar também uma viragem linguística. ${ }^{4}$

A linguagem, como Heidegger viria a afirmar, é a casa do Ser, e os seres humanos não são tanto senhores dela como seus pastores. Ao voltar-se desta forma para a linguagem, Heidegger acreditava ter encontrado uma abertura que lhe permitia expressar uma alternativa à filosofia ocidental de orientação metafísica e epistemológica que fazia com que, em última análise, os seres humanos se tornassem prisioneiros das suas próprias criações. À semelhança de outros filósofos ocidentais que o antecederam, Heidegger acreditava estar a defrontar-se com um momento único e que as perspectivas filosóficas desempenhavam um papel fundamental na sustentação de ideias e projectos históricos definidores desse momento. $\mathrm{O}$ momento em causa era, a seu ver, a crise da Europa expressa no niilismo ocidental e no desenraizado cosmopolitismo dos modelos liberais de Estado-nação desenhados no contexto da Revolução Francesa (Bambach, 2003: 6). Charles Bambach examinou com minúcia as ligações entre o pensamento de Heidegger e os termos com que este definiu e procurar enfrentar aquilo que considerava ser a crise da Europa. Uma breve exploração das teses de Bambach a respeito do projecto e do discurso filosófico de Heidegger elucidar-nos-á de que a viragem ontológica e linguística de Heidegger não pode ser compreendida na totalidade sem que se perceba na sua obra uma viragem geopolítica que veio conferir uma nova base ao racismo.

Em Heidegger's Roots, Bambach analisa a obra de Heidegger no contexto de debates políticos e intelectuais em torno da crise da Europa. Vários pensadores alemães concebiam esta crise não como a crise da Europa per se, mas como uma crise do centro da Europa (Bambach, 2003: 137). Para eles, no centro da Europa encontravam-se a Alemanha e o Volk ${ }^{5}$ alemão. A crise da Europa viria, desta forma, a ser entendida como uma crise do Volk alemão e do ambiente rural em que grande parte dele vivia. Neste contexto, era importante o mito ateniense da autoctonia, segundo o qual o fundador de Atenas, Erictónio, se havia concebido a si próprio a partir da terra (Bambach, 2003: 52). Este mantinha uma relação indígena com a terra e a paisagem atenienses. A visão do mito é clara: a grandeza de Atenas

\footnotetext{
${ }^{4}$ Para uma reflexão sobre a viragem de Heidegger, ver Risser, 1999.

${ }^{5}$ Povo $[N$. da T.]
} 
dependia de uma relação igualmente íntima entre os cidadãos de Atenas e o seu solo. $\mathrm{Na}$ Alemanha, muitos pensadores consideravam a crise política do seu país em termos similares. Só a afirmação das raízes da terra poderia resistir à força do niilismo e do cosmopolitismo desenraizado do Iluminismo francês. E essas raízes encontravam-se, precisamente, no mundo dos Gregos. Bambach refere que

Numa época em que a cultura alemã se desenvolvia sem o enquadramento de um Estado-nação unificado, uma série de filósofos e escritores recorria aos termos da sua visão da Antiguidade para afirmar os seus ideais nacionais. No contexto desta helenomania alemã, fortalecida pela invasão napoleónica de 1806, Fichte, Hegel e os seus contemporâneos viriam a invocar o mito de uma singular afinidade greco-germânica enraizada quer na linguagem, quer na Heimat. (Bambach, 2003: 116)

Uma das principais observações de Bambach é a de que a viragem ontológica e linguística de Heidegger representa uma expressão original da procura de um lar ou pátria (Heimat). ${ }^{6}$ Enquanto Erictónio continua a ser o modelo para o mito político das raízes firmadas na terra, Heidegger considera que o pensamento pré-socrático, "que brota da arche do próprio ser", é a raiz genuína do pensamento - um modo de pensar que iria contrastar fortemente com a metafísica e a epistemologia ocidentais. (Bambach, 2003: 112)

A localização de uma arche na Grécia esteve por trás da tentativa de tornar a Alemanha (a língua alemã e o Volk alemão) na nova arche da Europa. A geopolítica de Heidegger é, como refere Bambach, uma política baseada na relação íntima entre o povo, a sua língua e a sua terra. A geopolítica é, simultaneamente, uma política da terra e uma política de exclusão. Havia que proteger a Alemanha do "espírito francês do Iluminismo e da latinidade tanto da cultura gaulesa como da igreja católica.” (Bambach, 2003: 117). A geopolítica também se torna, para Heidegger, uma política de um racismo e de um imperialismo epistémicos. O racismo e o imperialismo epistémicos não são modalidades novas do mundo de Heidegger. De certa maneira, foram parte intrínseca da modernidade ocidental, antecedendo os excessos

\footnotetext{
${ }^{6}$ As considerações de Bambach acerca da metafísica heideggeriana da Heimat contrastam com a visão de espacialidade e de existência que, segundo Alejandro Vallega, se podem encontrar na obra de Heidegger. Ao contrário do projecto de Bambach, o de Vallega é mais construtivo e filosófico do que histórico ou arqueológico. Mas, tendo em conta a meticulosa procura da concepção heideggeriana de "raízes" empreendida por Bambach, Vallega tem de demonstrar, de forma clara, em que medida pode verdadeiramente atribuir a Heidegger um conceito de "terras de exílio". Também tem de mostrar, com exactidão, como esta concepção de espaço, em última análise, não se encontra associada à geopolítica racista de Heidegger (Vallega, 2003).
} 
tecnológicos ocidentais que Heidegger achava tão problemáticos. Ao explicar a crise da Europa em termos de niilismo e de tecnologia, e não nos termos desse racismo epistémico, Heidegger sentiu-se justificado na aventura que foi fazer à Europa o que a Europa fizera ao resto do mundo: a subordinação epistémica. A entrevista que deu à revista Der Spiegel deixa isto bem claro.

Spiegel: É precisamente no mesmo sítio em que o mundo tecnológico teve origem, que ele, a seu ver, tem de...

Heidegger: ... ser transcendido [aufgehoben] no sentido hegeliano do termo, não posto de parte, mas transcendido, ainda que não só através do homem.

$\mathrm{S}$ : Atribui aos Alemães, em particular, uma tarefa especial?

H: Sim, no sentido do diálogo com Hölderlin.

S: Acredita que os Alemães estão especialmente qualificados para esta inversão?

H: Tenho em mente sobretudo a relação íntima da língua alemã com a língua dos

Gregos e com o pensamento deles. Hoje, os Franceses voltaram a confirmar-me isso mesmo. Quando começam a pensar, falam alemão, sendo certo que não o conseguiriam fazer na sua própria língua.

S: O que nos está a dizer é que foi por isso que teve uma influência tão forte nos países de língua românica, em especial entre os Franceses?

H: Porque eles vêem que já não conseguem sobreviver no mundo contemporâneo com toda aquela sua grande racionalidade, quando se trata de compreender o mundo na origem do seu ser. (Heidegger, 1993a)

A ideia de que as pessoas não conseguem sobreviver sem as conquistas teóricas ou culturais da Europa é um dos mais importantes princípios da modernidade. Há séculos que esta lógica é aplicada ao mundo colonial. Heidegger retomou esta tradição mas transformou-a de modo a, através do germanocentrismo, poder fazer ao resto da Europa o que a Europa tinha feito a uma grande parte do globo. Esta viragem epistémica não surpreende, se considerarmos que, não muitos anos antes de Heidegger ter feito estas afirmações, os Alemães tinham ocupado Paris. De facto, em certos aspectos, como Aimé Césaire tão bem fez notar, os Alemães tentaram fazer à Europa, no plano político, aquilo que a Europa tinha feito ao mundo colonial (Césaire, 1978). Heidegger levou por diante este projecto, mas num sentido filosófico mais estrito. Na verdade, esta interpretação epistémica do projecto não o torna menos ideológico ou racista.

As atitudes heideggeriana e nazi em relação à Europa tiveram antecedentes. Entre os finais do século XVI e o século XIX, os Franceses e os Ingleses haviam traçado uma linha divisória entre a Europa do Norte e a Europa 
do Sul. ${ }^{7}$ A diferença foi surgindo gradualmente através da propagação da Lenda Negra, do prestígio do avanço tecnológico e da asserção do poder colonial em África e no Sudeste Asiático. Os Franceses e as revoluções industriais forneceram justificações acrescidas para que Portugal e Espanha fossem marginalizados da história da modernidade. O aparecimento de novas disciplinas no sistema universitário ocidental moderno durante o século XIX e a sua contínua expansão ao longo do século XX só vieram cimentar a posição subalternizada da Europa do Sul. A viragem linguística de Heidegger repete alguns destes padrões. A diferença é que, enquanto alguns estabeleciam uma divisão entre Europa do Norte e Europa do Sul, ele e outros pensadores conservadores alemães postulavam a metafísica da Mitteleuropa. Para Heidegger, o novo início está no meio. E o meio é, precisamente, o que é ameaçado, primeiro pelos ideais franceses e depois pelas forças estrangeiras. Os pensadores conservadores alemães insistiram, desde cedo, na ameaça da Zivilization da França contra a Kultur da Alemanha. Como Bambach assinala, Heidegger não só comungou desta posição, como também chamou a atenção para a ameaça de duas potências emergentes: a União Soviética, por um lado, e os Estados Unidos da América, por outro.

A União Soviética tinha-se tornado uma importante força política após a Revolução Bolchevique de 1917. Depois de Hitler ter quebrado o Tratado de Versalhes, na década de 30, a França fez um pacto com a União Soviética. O objectivo era, claramente, deixar a Alemanha isolada no centro. Em 1936, consciente da aliança entre o cosmopolitismo desenraizado da França e a "asiática” União Soviética, Heidegger afirmava:

O nosso Dasein histórico sente, com uma clareza e apreensão crescente, que o seu futuro equivale a uma nua e crua alternativa: ou o salvamento da Europa, ou a sua destruição. Porém, a possibilidade de salvamento exige duas coisas:

1. A preservação dos Völker europeus contra os asiáticos.

2. A superação do seu próprio desenraizamento e fragmentação.

Sem essa superação será impossível concretizar essa preservação. (Heidegger, 1993b, apud Bambach, 2003: 167-168)

Embora Heidegger tenha mantido o seu germanocentrismo até ao fim, algumas das ideias centrais da sua posição traduziu-as para uma forma mais alargada de eurocentrismo. É certo que o seu eurocentrismo ainda pressupunha um forte germanocentrismo. De certa forma, a defesa da Europa tornou-se um prolongamento da sua diatribe contra o pensamento francês

\footnotetext{
7 Para uma elucidação sobre a diferença imperial entre a Europa do Norte e do Sul, ver Mignolo, 2000.
} 
sobre quem era o dono do legado europeu. O pacto da França com a União Soviética indicava bem quão pouco europeu aquele país se mostrava capaz de ser. O mais desconcertante em tudo isto é que, para Heidegger, a ameaça mais perigosa para a Europa não vinha não do anti-semitismo e das políticas imperiais de Hitler, mas da reacção da França à violação do Tratado de Versalhes pelo Führer.

Heidegger foi muito claro também em relação à ameaça dos Estados Unidos. Em 1942, após a entrada dos Americanos na Segunda Guerra Mundial, escrevia: "sabemos hoje que o mundo anglo-saxónico do Americanismo decidiu aniquilar a Europa, ou seja, a pátria [Heimat], e isso significa: o princípio de um Mundo Ocidental” (Heidegger, 1996b, apud Bambach, 2003: 177). Bambach resume o ponto de vista de Heidegger sobre a América da seguinte forma:

Apoiando-se numa série de declarações de Hegel, Burckhardt, Nietzsche, Scheler, Jünger, Rilke, entre outros, Heidegger considerava a América (termo com que pretendia designar Estados Unidos) uma terra sem história, uma cultura sem raízes, um povo aprisionado nas garras mortíferas de uma mobilização total, preocupado com o tamanho, a expansão, a magnitude e a quantidade ... Visto no contexto da sua interpretação geopolítica da Mitteleuropa, o Americanismo simboliza a falta de raízes, a perda da autoctonia e de toda e qualquer ligação significativa com a terra. (Bambach, 2003: 163)

As geopolíticas filosóficas de Heidegger eram ambiciosas, grandiosas e racistas. Como bem observa Bambach, Heidegger, não obstante opor-se ao racismo biológico dos ideólogos nazis, manteve, mesmo assim, uma forma de racismo (Bambach, 2003: 5). O seu racismo não é biológico, nem cultural, mas sim epistémico. Tal como acontece com todas as formas de racismo, o epistémico está relacionado com a política e a socialidade. O racismo epistémico descura a capacidade epistémica de certos grupos de pessoas. Pode basear-se na metafísica ou na ontologia, mas os resultados acabam por ser os mesmos: evitar reconhecer os outros como seres inteiramente humanos.

O racismo de Heidegger era muito claro na sua percepção dos judeus e da tradição hebraica. Numa carta escrita a um colega em 1929, afirma:

Gostaria de ser mais claro acerca daquilo a que apenas fiz uma breve referência no meu relatório. Em causa está, nada mais, nada menos do que a premente consideração de que nos encontramos perante uma escolha: ou damos, uma vez mais, à vida espiritual alemã forças genuínas e educadores radicados no que há de vernáculo e autóctone, ou acabamos por entregá-la à crescente judaização. (Bambach, 2003: 53) 
A visão que Heidegger tinha dos Judeus assentava na ontologia nacionalista da pátria (Heimat). Aos seus olhos, a vivência do êxodo e da diáspora transformava os Judeus em sujeitos intrinsecamente desenraizados (Bambach, 2003: 53). Considerava que os judeus eram uma ameaça à pátria. Dotada de uma identidade urbana e não rural, esta gente errante desafia o princípio ateniense da autoctonia. Por este motivo, mesmo os judeus que falavam a língua alemã ainda representavam uma ameaça para o Volk germânico. O facto de Heidegger ter um sentimento de gratidão para com o seu professor Edmund Husserl não representa uma excepção ao que foi dito. A Heidegger não o preocupava tanto cada indivíduo per se, mas sim a "crescente judaização", a qual tem que ver, não com a sua relação com um qualquer judeu em particular, mas com a sua atitude perante a influência colectiva globalmente exercida pelos Judeus na Alemanha.

É claro que o racismo epistémico de Heidegger não passou sem contestação. Um dos mais virulentos críticos de Heidegger, senão mesmo o mais virulento de todos eles, foi um antigo aluno de Edmund Husserl em Freiburgo, que também frequentou as aulas de Heidegger: Emmanuel Lévinas. Toda a obra mais madura de Lévinas é uma tentativa de subversão do pensamento de Heidegger. Na sua primeira grande obra, Totalidade e infinito, Lévinas descreve a ontologia como uma filosofia do poder (Lévinas, 1988). Em contraposição à ontologia heideggeriana, Lévinas propôs a ética como filosofia primeira. E esta ética tinha uma base sólida precisamente naquilo em que Heidegger não conseguia encontrar valor nenhum: a tradição hebraica. Se a crítica ao Ocidente feita por Heidegger tem por base o pretenso esquecimento do Ser, a crítica empreendida por Lévinas assenta antes no esquecimento do factor hebraico por parte do pensamento ocidental. Lévinas encontrou nas fontes judaicas a possibilidade de expressar uma metafísica ética que impunha limites às ideias cristãs e liberais acerca da autonomia do sujeito. As fontes judaicas também lhe deram algumas pistas para desenvolver uma concepção de corporalidade muito diferente da lógica racial nazi. ${ }^{8}$

A viragem ética de Lévinas na filosofia salva a relevância epistémica do judaísmo ao mesmo tempo que retém o legado grego. Tal como Husserl já tinha feito, o que ele aproveitou e valorizou dos Gregos não foi o mito da autoctonia, mas a ideia de universalidade. Lévinas insistia que essa ideia de universalidade era perfeitamente compatível com as fontes judaicas. Para

\footnotetext{
${ }^{8}$ Aprofundei esta questão num texto inédito intitulado 'Against War: Views from the Underside of Modernity' ('Contra a guerra: perspectivas do reverso da modernidade').
} 
ele, a filosofia tornou-se precisamente a fusão criativa das fontes gregas e judaicas. A seu ver, Atenas e Jerusalém não constituíam princípios opostos, mas sim coabitações do universal no humano.

Lévinas respondeu de forma directa ao racismo epistémico de Heidegger, tentando demonstrar que os Judeus não podiam ser excluídos da Europa ou do Ocidente por causa de alegadas diferenças epistémicas. A vivência e o conhecimento hebraicos baseados numa combinação das tradições de pensamento hebraicas e gregas não eram, neste aspecto, extra-ocidentais; eram, de certa forma, paradigmaticamente ocidentais. Lévinas reconfigurou a ideia do Ocidente e tentou construir um quadro filosófico alternativo que respondesse às ameaças de racismo e violência e que, simultaneamente, tornasse clara a relevância epistémica do judaísmo.

Lévinas tinha uma geopolítica filosófica diferente da de Heidegger. Ele conseguia imaginar Atenas e Jerusalém lado a lado, servindo de alicerce ao Ocidente. A questão é até que ponto esta aliança respondia satisfatoriamente aos desafios com que se confrontavam outras regiões e cidades do mundo. Enquanto Heidegger se apega ao chão ou à terra do ambiente rural, ao mito da autoctonia grega e ao alemão como língua do Volk do centro da Europa, Lévinas está mais determinado em adoptar o cosmopolitismo da experiência urbana, embora as únicas línguas que lhe ocorram como veículo legítimo do pensamento sejam o grego e o hebraico. Finalmente, só Atenas e Jerusalém se destacam, na sua obra, como cidades do conhecimento. De algum modo, Lévinas escreve como se a inclusão epistémica do judaísmo na dinâmica interna do Ocidente bastasse para enfrentar a exclusão epistémica em todos os outros locais. Assim, ainda que Lévinas tenha defendido, com êxito, os Judeus e o judaísmo em relação ao racismo epistémico heideggeriano (em relação, de facto, a um racismo epistémico endémico a grande parte da filosofia moderna), ele não escapa à lógica heideggeriana da busca de raízes nem à sua tendência para pensar a epistemologia apenas por referência às grandes realizações do mundo ocidental. Na sua qualidade de judeu europeu, Lévinas procura raízes no Ocidente e, assim, transforma a ideia hegemónica do Ocidente de modo a encaixar nela. Contudo, só parcialmente transgride o discurso de Heidegger (e de grande parte da filosofia europeia), pois continua preocupado com a busca de raízes e com a defesa da ideia de Europa (e, evidentemente, de Israel) enquanto projecto. A sua geopolítica encontra-se, portanto, limitada pelo seu forte desejo de encontrar raízes na Europa.

Onde poderá encontrar-se uma resposta mais radical para o projecto de Heidegger? Lévinas tem uma resposta crítica para a visão anti-semita de Heidegger. No entanto, o racismo epistémico de Heidegger, tal como o 
de muitos filósofos europeus, vai muito além desse âmbito. Não era só em relação a Jerusalém que Heidegger se mostrava céptico. Tal como já vimos, em causa estavam também Roma, a Ásia Menor, a Rússia e a América. Heidegger enunciou a sua filosofia num contexto em que o imperialismo europeu estava a ser alvo de uma contestação provinda de várias direcções. Tendo em consideração este contexto geopolítico mais amplo, Bambach coloca em confronto os esforços de Heidegger no sentido de encontrar raízes no Ocidente com os de Frantz Fanon, psiquiatra e filósofo natural da ilha Martinica (Bambach, 2003: 177-178). Fanon, que se bateu contra os Alemães na Segunda Guerra Mundial e, mais tarde, contra o imperialismo francês na guerra da Argélia, tinha em mente não apenas a difícil situação dos Judeus durante o Holocausto, mas também a situação de outras vítimas do ethos imperial e racista europeu noutras partes do mundo, especialmente no mundo colonial. Esta experiência histórica e este seu comprometimento político levaram Fanon a afirmar, de forma claramente contrastante com Heidegger e Lévinas, que

O jogo europeu está definitivamente acabado; é preciso encontrar outra coisa... Durante séculos, em nome de uma pretensa aventura espiritual, [os Europeus] sufocaram quase toda a humanidade. Vejam-nos hoje oscilar entre a desintegração atómica e a desintegração espiritual [...]. A Europa adquiriu uma tal velocidade, louca e desordenada, que escapa hoje em dia a todo o condutor e a toda a razão [...]. Foi em nome do espírito, do espírito europeu, bem entendido, que a Europa justificou os seus crimes e legitimou a escravidão em que mantém quatro quintos da humanidade. Sim, o espírito europeu teve raízes singulares. (Fanon, 1975-1976: 312)

O comentário de Bambach em relação a este passo é esclarecedor: “À semelhança de Fanon, Heidegger percebeu que a Europa "se precipitava de cabeça para o abismo'. Contudo, enquanto o antigo colonizado percebeu a necessidade da diferença, Heidegger procurou a saída para a crise da Europa na possibilidade de uma forma de identidade mais restrita (Bambach, 2003: 178). Perante uma usurpação que não é exclusiva do projecto heideggeriano da busca de raízes na Pátria alemã, uma usurpação e um racismo que durante séculos se haviam apresentado aos povos colonizados em várias regiões do globo, Fanon veio propor uma deslocação radical da Europa e respectivas raízes. Para Fanon, a modernidade/niilismo não eram senão uma outra expressão da modernidade/racismo, a vil segregação e a pretensão de superioridade da Europa sobre todos os outros povos da Terra (Fanon, 1975). A geopolítica filosófica de Fanon era transgressiva, descolonial e cosmopolita. Era sua intenção trazer à luz o que tinha permane- 
cido invisível durante séculos. Reclamava a necessidade do reconhecimento da diferença, assim como a necessidade da descolonização enquanto requisito absoluto para o adequado reconhecimento da diferença humana e da concretização de uma forma de humanismo pós-colonial e pós-europeu (Fanon 1965, 1988).

O cosmopolitismo descolonial de Fanon assentava na luta do povo argelino pela descolonização. O seu cosmopolitismo não sacrificou o comprometimento com a luta local. Mais do que um cosmopolitismo propriamente dito, talvez se deva caracterizar este projecto como uma tentativa de dar expressão a uma consciência descolonial consistente. Para Fanon, a descolonização não se resume a alcançar a libertação nacional, antes implica a criação de uma nova ordem material e simbólica que leva em consideração o espectro completo da história humana, incluindo as suas conquistas e fracassos. É este o lado da história que nem Heidegger nem Lévinas conseguiram - ou quiseram - ver. A procura de raízes europeias cegou-os para este tipo de geopolítica descolonial. Ao invés de dar primazia à busca de raízes na Europa ou noutro lado qualquer, a consciência descolonial de Fanon pretende deslocar o sujeito, sensibilizando para uma resposta aos que se encontram aprisionados em posições de subordinação. Em vez de tentar encontrar raízes na terra, Fanon propôs-se dar uma resposta responsável aos condenados da terra. A geopolítica descolonial de Fanon oferece uma alternativa ao racismo filosófico de Heidegger e às perspectivas limitadas daqueles que, à semelhança de Lévinas, embora sejam críticos em relação a certos aspectos deste projecto, continuam, de alguma forma, a ser cúmplices dele.

O racismo de Heidegger e a cegueira de Lévinas reflectem aquilo que, na sua vontade-de-ignorar, pode ser traduzido, em parte, como um esquecimento da condenação. O esquecimento dos condenados faz parte integrante da verdadeira doença do Ocidente, uma doença comparável a um estado de amnésia que por sua vez leva ao homicídio, à destruição e à vontade epistémica de poder - mantendo sempre uma boa consciência. A oposição à modernidade/racismo tem de saber lidar com esta amnésia e com a invisibilidade dos condenados. Para tal, é necessária uma visão histórica que combine espaço e tempo. Um grupo de académicos da América Latina e dos Estados Unidos tem vindo a trabalhar numa perspectiva geopolítica que resgata aquilo que designam por lógica da colonialidade. Referir esta lógica permite que se faça referência não só à opressão ontológica, como também à colonialidade do Ser. Nesta minha tentativa de encontrar uma via crítica mais radical do que aquela que foi desbravada pelos projectos filosóficos de Heidegger e Lévinas, passarei a expender, na secção seguinte, 
alguns dos dados e desenvolvimentos teóricos que apontam nesta direcção. Eles constituem uma importante parte daquilo que se poderia designar como meditações fanonianas. ${ }^{9}$

\section{Modernidade, colonialidade e a colonialidade do ser}

O conceito de colonialidade do Ser surgiu no decurso de conversas tidas por um grupo de académicos da América Latina e dos Estados Unidos, acerca da relação entre a modernidade e a experiência colonial. ${ }^{10}$ Ao inventar este termo, seguiram as passadas de estudiosos como Enrique Dussel e o sociólogo peruano Aníbal Quijano, que propuseram uma explicação da modernidade e uma concepção de poder intrinsecamente ligadas à experiência colonial (Dussel, 1996; Quijano, 2000). À primeira vista, parece existir uma dissonância entre o tema da modernidade e a relação imperial/colonial. Um dos conceitos tem a ver com tempo (o moderno), enquanto o outro faz referência ao espaço (expansionismo e controlo das terras). Dir-se-ia que a modernidade implica a colonização do tempo pelo europeu, isto é, a criação de estádios históricos que conduziram ao advento da modernidade em solo europeu. Todavia, os próprios laços que ligam a modernidade à Europa nos discursos dominantes da modernidade não conseguem deixar de fazer referência à localização geopolítica. O que o conceito de modernidade faz é esconder, de forma engenhosa, a importância que a espacialidade tem para a produção deste discurso. É por isso que, na maioria das vezes, aqueles que adoptam o discurso da modernidade tendem a adoptar uma perspectiva universalista que elimina a importância da localização geopolítica. Para muitos, a fuga ao legado da colonização e da dependência é facultada pela modernidade, como se a modernidade enquanto tal não tivesse estado intrinsecamente associada à experiência colonial.

Os problemas da modernidade vão além dos excessos da racionalidade instrumental. A cura para eles, se é que existe, reside muito para além da virtude redentora de uma viragem comunicativa supostamente intrínseca, como recomenda Jürgen Habermas. ${ }^{11}$ A concepção de modernidade de

\footnotetext{
${ }^{9}$ Fanonian Meditations (Meditações Fanonianas) é o título do projecto de livro que tenho, presentemente, em mãos.

${ }^{10}$ Entre os académicos que participaram nestas conversas contam-se Santiago Castro-Gómez, Fernando Coronil, Enrique Dussel, Arturo Escobar, Ramón Grosfoguel, Eduardo Lander, Eduardo Mendieta, Walter Mignolo, Aníbal Quijano, Ana Margarita Cervantes-Rodríguez, José David Saldívar, Freya Schiwy e Catherine Walsh, entre outros. Walter Mignolo foi o primeiro a sugerir o conceito de colonialidade do ser. Nem todos os participantes nas referidas conversas partilham o mesmo entusiasmo em relação a este conceito.

${ }^{11}$ Refiro-me aqui à proposta de Habermas contida em Habermas, 1990, entre outros.
} 
Habermas, dos seus limites e possibilidades, não teve suficientemente em conta os laços existentes entre a modernidade europeia e aquilo que J.M. Blaut denomina mito difusionista do vazio. Como escreve Blaut,

Esta proposição do vazio reivindica uma série de coisas, cada uma delas sobreposta às restantes em camadas sucessivas: (i) Uma região não-europeia encontra-se vazia ou praticamente desabitada de gente (razão pela qual a fixação de colonos europeus não implica qualquer deslocação de povos nativos). (ii) A região não possui uma população fixa: os habitantes caracterizam-se pela mobilidade, pelo nomadismo, pela errância (e, por isso, a fixação europeia não viola nenhuma soberania política, uma vez que os nómadas não reclamam para si o território). (iii) As culturas desta região não possuem um entendimento do que seja a propriedade privada - quer dizer, a região desconhece quaisquer direitos e pretensões à propriedade (daí os ocupantes coloniais poderem dar terras livremente aos colonos, já que ninguém é dono delas). A camada final, aplicada a todos os do sector externo, corresponde a um vazio de criatividade intelectual e de valores espirituais, por vezes descrito pelos europeus [...] como sendo uma ausência de 'racionalidade'. (Blaut, 1993: 15)

O discurso da modernidade não permitiu aos seus inflexíveis seguidores explorar o modo como as concepções imperiais de espaço têm sido elementos de formação da experiência moderna. Quais são as relações entre, por um lado, as tendências instrumentalistas e monológicas da modernidade e, por outro, o mito do vazio das terras e do vazio de racionalidade dos povos dessas terras? Como se pode comunicar com sujeitos que a priori se suspeita não serem dotados de razão? A fim de abordar estas questões, é necessário introduzir um conceito de modernidade que tenha seriamente em consideração a relação que esta mantém com as relações geopolíticas. Isto é o que, em parte, o grupo da colonialidade dos Estados Unidos e da América Latina vem tentando fazer há já alguns anos.

Tal como salientou Walter Mignolo (2000), uma das formas mais eficazes de evitar as questões atinentes ao papel da experiência colonial da modernidade tem sido situar o nascimento da era moderna nos finais o século XVIII. É verdade que os estudos pós-coloniais chamaram a atenção para as questões da espacialidade e da colonialidade. No entanto, na maioria dos casos os investigadores dos estudos pós-coloniais acatam a autodefinição da modernidade, e em particular a fixação temporal do seu início, entre os finais do século XVIII e princípios do século XIX. Assim, embora sejam capazes de ilustrar o modo como as aventuras imperiais da Grã-Bretanha e da França no século XIX foram constitutivas da modernidade ocidental, acabam por perder de vista os padrões de mais longo prazo da dominação 
e exploração colonial..$^{12}$ Por exemplo, não é possível compreender os laços existentes entre a modernidade e o mito difusionista do vazio de que Blaut fala, sem ter em conta a descoberta e a conquista das Américas. É por esta razão que Quijano e Wallerstein atribuem à americanidade um papel central na explicação que oferecem da modernidade:

Nas Américas [...] houve uma tamanha destruição generalizada das populações indígenas, especialmente entre as populações recolectoras, e uma tamanha importação generalizada de mão-de-obra, que o processo de periferização envolveu não tanto a reconstrução das instituições económicas e políticas como a sua construção, praticamente a partir do zero e um pouco por todo o lado (exceptuando talvez as zonas do México e dos Andes). Por esse motivo, desde o início o modo de resistência cultural às condições opressivas residiu menos nas pretensões de historicidade do que na fuga em frente, rumo à 'modernidade'. As Américas eram o 'Novo Mundo', uma divisa e um fardo assumidos desde os primórdios. Porém, à medida que os séculos foram passando, o Novo Mundo foi-se tornando o padrão, o modelo de todo o sistema-mundo. (Quijano e Wallerstein, 1992)

Suscitar a questão da relação entre modernidade e experiência colonial na América Latina e em outras zonas das Américas, especialmente se tal for feito por sujeitos cépticos relativamente às promessas da modernização e às qualidades "redentoras" do Estado-nação, é salientar a relevância do que Quijano e Wallerstein referem como sendo o longo século XVI na produção da modernidade. Se, por um lado, é certo que as aventuras imperiais do século XIX introduziram novas técnicas de subordinação e de controlo colonial, reformulando, assim, de uma forma original, os laços entre a modernidade e a experiência colonial, por outro lado, a lógica que animou os projectos imperiais não foi assim tão diferente dos padrões que emergiram no contexto da conquista das Américas. De facto, seria impossível compreender esta lógica sem lhes fazer referência. A consciência dos padrões de longo prazo de racialização, dominação e dependência, testados e postos em prática no contexto da conquista das Américas (mas que obviamente se não restringiram ao território americano) foi o que levou alguns académicos da América Latina e alguns académicos 'latinos' dos Estados Unidos, incluindo gente envolvida em confrontos indígenas na América do Sul, a entrar num diálogo crítico com perspectivas como as defenddidas por Quijano ou Wallerstein, que identificam a existência de padrões de relações de

${ }_{12}$ Isto aplica-se a Edward Said, Gayatri Spivak e Homi Bhabha, entre outros. Analiso alguns dos limites da crítica pós-colonial em Maldonado-Torres, no prelo. 
poder de longo prazo naquilo que viemos a chamar modernidade. Se a teoria pós-colonial, por um lado, constituiu um enorme contributo para a compreensão da modernidade na sua relação com a experiência colonial e a deslocação do Estado-nação enquanto unidade de análise - ideias que ainda têm de ser assumidas por inteiro a partir da perspectiva do sistemamundo -, por outro lado, ela também se arrisca a tomar como certa a narrativa da modernidade: veja-se, a este propósito, a sua fixação no secularismo, a sua crítica à tradição, o retrato que traça dos impérios de Espanha e Portugal, e os seus múltiplos sujeitos coloniais entendidos como antecedentes insignificantes da modernidade ocidental. A ideia aqui é que, embora seja verdade que a "Grã-Bretanha moderna foi produzida conjuntamente com a Índia moderna”, é impossível explicar cabalmente a "modernidade" destas nações sem, de todo, fazer referência a um quadro mais vasto que torne visíveis as experiências dos povos colonizados das Américas ou de outros locais, pelo menos a partir do século XVI. ${ }^{13}$ Como Sylvia Wynter insiste em afirmar, também é especialmente relevante a relação de África, primeiro, com a Europa do Sul e, depois, com a Europa do Norte (Wynter, 1995 e 2000; Mudimbe, 1988). A relação da Europa com África é constitutiva tanto da primeira como da segunda modernidade.

De acordo com Wynter e com estudiosos como Aníbal Quijano, o que emerge no século XVI é uma nova maneira de classificar os povos de todo o mundo. ${ }^{14}$ Quando os mappae-mundi medievais passam a Orbis Universalis Christianus, ocorre uma significativa mudança na concepção dos povos e do espaço. À medida que iam sendo desenhados os mapas, descritos os povos e estabelecidas as relações entre conquistadores e conquistados, foi emergindo um novo modelo de poder. Segundo Quijano,

Dois processos históricos associados na produção daquele espaço/tempo convergiram e estabeleceram os dois eixos fundamentais do novo modelo de poder. Um consistiu em codificar, na ideia de 'raça', as diferenças entre conquistadores e conquistados, uma estrutura biológica supostamente diferente que colocava uns numa situação de natural inferioridade em relação aos outros... O outro processo foi a constituição de

\footnotetext{
${ }^{13}$ As referências à Grã-Bretanha e à índia modernas aparecem em van der Veer (2001: 7).

${ }^{14} \mathrm{Se}$ as concepções de Wynter respeitantes à modernidade, à raça e ao poder provêm da tradição de W.E.B. Du Bois e Frantz Fanon, a teorização que Quijano faz destes conceitos remonta à teoria da dependência da América Latina e à obra de José Carlos Mariátegui. Wynter e Quijano são "hereges" do pós-estruturalismo e do marxismo, respectivamente. É extremamente necessário que exista um maior diálogo entre estas "heréticas" tradições críticas. Uso o conceito de heresia na acepção desenvolvida por Anthony Bogues em Black Heretics (Bogues, 2003). Quanto às obras de Quijano e Wynter, ver em especial Quijano, 2000, e Wynter, 1995. Para mais referências sobre a emergência da ideia de raça no século XVI, ver Mignolo, 2003 b.
} 
uma nova estrutura de controlo do trabalho, dos seus recursos e produtos. Esta nova estrutura traduzia todas as estruturas historicamente já conhecidas de controlo do trabalho, da escravatura, da servidão, da pequena produção independente de mercadorias e da reciprocidade, em torno e em função do capital e do mercado mundial. (Quijano, 2000: 532-533)

O novo padrão de dominação e exploração envolvia uma articulação entre raça e capitalismo na criação e crescente expansão da rota comercial atlântica. Quijano referiu-se a esta complexa matriz de poder como colonialidade do poder. "Colonialidade do poder" é um modelo de poder especificamente moderno que interliga a formação racial, o controlo do trabalho, o Estado e a produção de conhecimento (Quijano, 2001). No entanto, este carácter constitutivo da experiência colonial e da colonialidade perdem-se nas explicações de modernidade que desprezam a importância que as relações espaciais tiveram para a emergência do mundo moderno. Para abordar esta situação, Mignolo introduz o conceito de mundo colonial/moderno. Conceitos como o de Renascimento e período pré-moderno tendem a apagar o significado da espacialidade e da colonialidade. Para Mignolo,

A expressão colonial/moderno tem, relativamente a periodo pré-moderno, a vantagem de introduzir uma noção espacial que este último não possui. Periodo pré-moderno pressupõe uma narrativa linear e ascendente que vem em desde a Antiguidade, atravessa a Idade Média, a era pré-moderna, a moderna e a contemporânea. Em termos de espaço, uma macronarrativa deste tipo é delimitada pelo território que abarca desde a parte leste e norte do Mediterrâneo até ao Atlântico Norte, e pressupõe o Ocidente como moldura global. Em contraste com isto, a expressão mundo colonial/moderno convoca todo o planeta, na medida em que contempla, em simultâneo, o aparecimento e expansão do circuito comercial atlântico, a sua transformação com a Revolução Industrial, e a sua expansão para as Américas, Ásia e África. Além disso, mundo colonial/moderno abre a possibilidade de contar histórias não só a partir da perspectiva do 'moderno' e da sua expansão para o exterior, mas também a partir da perspectiva do 'colonial' e da sua permanente posição subalterna. (Mignolo, 2002: 452; sublinhados no original)

A “colonialidade do poder" chama a atenção para a questão da espacialidade e exige um conceito do moderno que reflicta o papel constitutivo da colonialidade na ideia do moderno. Como afirma Mignolo, num contexto diferente, "[a] colonialidade do poder abre uma porta analítica e crítica que revela o lado mais escuro da modernidade e o facto de nunca ter existido, nem poder vir a existir, modernidade sem colonialidade" (Mignolo, 2003a: 633). 
Foi com base nestas reflexões sobre a modernidade, a colonialidade e o mundo moderno/colonial que surgiu o conceito de colonialidade do Ser. A relação entre poder e conhecimento conduziu ao conceito de ser. E se, então, existia uma colonialidade do poder e uma colonialidade do conhecimento (colonialidad del saber), pôs-se a questão do que seria a colonialidade do ser. ${ }^{15}$ Mignolo expressou de forma sucinta a relação entre estes termos ao escrever:

A 'ciência' (conhecimento e sabedoria) não pode ser separada da linguagem; as línguas não são apenas fenómenos 'culturais' em que as pessoas encontram a sua 'identidade'; elas também são o lugar onde se inscreve o conhecimento. E, dado que as línguas não são algo que os seres humanos têm, mas algo de que os seres humanos são, a colonialidade do poder e a colonialidade do conhecimento engendraram a colonialidade do ser [colonialidad del ser]. (Mignolo, 2003a: 633)

Tal como Heidegger, Mignolo relaciona ser e linguagem. Mas ao contrário de Heidegger, que glorificou uma língua específica e adoptou uma forma forte de racismo epistémico, Mignolo indica o locus da colonialidade do ser como o ser-colonizado que forma o lado mais escuro das reflexões de Heidegger. Este ser-colonizado emerge quando poder e pensamento se tornam mecanismos de exclusão, tal como já haviam sido as propostas de Heidegger. É verdade que o ser-colonizado não resulta do trabalho de um determinado autor ou filósofo, mas é antes o produto da modernidade/colonialidade na sua íntima relação com a colonialidade do poder, com a colonialidade do saber e com a própria colonialidade do ser.

$\mathrm{Na}$ esteira de Fanon, o ser-colonizado podia ser também referido como damné - ou o condenado - da terra. Os damnés são aqueles que se encontram nas terras ermas dos impérios, assim como em países e megacidades transformados, eles próprios, em pequenos impérios - como sejam as "favelas" do Rio de Janeiro, a "villa miseria" de Buenos Aires, os sem abrigo e as comunidades marcadas pela pobreza extrema na Bronx, em Nova Iorque. Estes são os territórios e as cidades que, quase sempre, são simplesmente ignorados nas diatribes filosóficas sobre o lugar do saber. Vimos isto na secção anterior. Heidegger privilegiava Atenas e a Floresta Negra. Lévinas questionou este germanocentrismo situando a verdadeira filosofia (a "sabedoria do amor”) em Atenas e Jerusalém. O contraste entre Heidegger e Lévinas resume-se, até certo ponto, ao seguinte: enquanto Heidegger se atormentava com a judaização da Europa, Lévinas viu na filosofia uma

$\overline{15}$ Para aprofundar a noção de colonialidade do saber, ver Lander, 1993. 
oportunidade de combater o anti-semitismo epistémico e, assim, legitimar a presença dos Judeus na Europa e os seus contributos epistémicos para a civilização ocidental. O problema do projecto de Lévinas é que, no processo de redenção da tradição hebraica enquanto raiz significativa do Ocidente - sendo Atenas e Jerusalém as duas mais importantes fontes do pensamento ocidental -, Lévinas esquece ou põe de parte a relevância da experiência colonial nas reflexões sobre o ser e a modernidade. Por esse motivo, não foi capaz de tratar a questão da faceta colonial do Ser.

O esquecimento da colonialidade nas reflexões sobre o Ser não é exclusivo da tradição fenomenológica. Encontramo-lo, como já sugeri antes, em muitos outras explicações da modernidade que tendem a interpretar a dialéctica do Iluminismo apenas e só em termos de razão instrumental ou da emergência de regimes totalitários. Estas interpretações podem levar a uma crítica dos excessos do Ser como algo que é, de um modo geral, violento ou até mesmo genocida, mas não colonizador. Um passo de uma obra de Antonio Negri recentemente publicada em francês e espanhol mostra claramente o que quero dizer com isto:

O livro de Job é não apenas um protesto contra a sedução da razão, mas também a descoberta fenomenológica e a sugestão metafísica do desastre a que a coerência da razão instrumental conduz. A tragédia atinge o Ser e a dor penetra-o profundamente. O que não pode ser medido não pode ser nomeado. A razão fica louca e confusa se tentamos dar-lhe nome. A tragédia não pode ser vivida e muito menos manipulada ou dominada. A tragédia domina todas as perspectivas e bloqueia todos os meios de fuga possíveis. A tragédia derruba qualquer meio de salvação possível. É isto que acontece a Job. O obstáculo com que se confronta repete-se incessantemente na história: como acreditar na razão depois de Auschwitz ou Hiroxima? Como continuar a ser comunista depois de Estaline? (Negri, 2003: 33)

Em consonância com um tema que, com o trabalho da Escola de Frankfurt, se tornou moeda corrente, Negri explica a tragédia da modernidade à luz da extrema coerência da racionalidade instrumental. Tal como indicam as referências que faz a Auschwitz, Hiroxima e Estaline no final da citação, está claramente presente uma geopolítica no seu texto. A tragédia a que Negri se refere constitui (para um europeu) o fracasso mais evidente de três projectos da modernidade: o fascismo (Auschwitz), o liberalismo (o bombardeamento de Hiroxima pelos EUA) e o comunismo (Estaline na União Soviética). Aqui, a Alemanha, os EUA e a União Soviética surgem, não como loci de salvação ou como ameaças, a exemplo do que sucede em Heidegger, mas como lugares geopolíticos de crise. Negri começou a escrever o seu 
livro sobre Job em 1982-83, quando já estava na prisão e não lhe restava mais do que tentar conformar-se com a derrota. Da mesma forma que Heidegger se manteve alicerçado na Alemanha aprofundando os pontos de contacto entre o Alemão e o Grego, Negri, em tempos de crise, também cultiva as suas raízes ocidentais, mas através de uma reflexão sobre as fontes judaico-cristãs, neste caso, o Livro de Job. De certa forma, o essencial, para estes pensadores, é manter viva a modernidade ocidental. Esta forma de política hegemónica de identidade não seria tão problemática se não partisse do princípio de que a crítica da razão instrumental é suficiente para explicar a lógica da colonialidade. Em grande parte do pensamento crítico existe uma tendência para reconhecer a presença deste apenas quando usa os termos de debate resultantes da consideração de certas coordenadas, que, por regra, se situam em espaços cruciais para a produção de ideologias modernas e pós-modernas. Na geopolítica de Negri quase não existe uma reflexão séria sobre a condição do racismo ou do sexismo que é visível na relação do Ocidente com as suas colónias. As tragédias causadas por séculos de incursões, genocídios, de submissão e de segregação da maior parte do planeta parecem passar despercebidas no quadro que este autor traça do mal. É como se se quedassem por um papel secundário à luz das manifestações mais abertamente maléficas (para um europeu) das ideologias modernas. Contrariamente a esta atitude, Fanon tentou debruçar-se sobre as formas do mal tal como se apresentam em Auschwitz e na Argélia, em Hiroxima e nas Caraíbas Francesas, na União Soviética e onde quer que as vidas de alguns seres humanos se hajam afigurado dispensáveis aos olhos de outros. Visto desta perspectiva, o mal não aparece como um acontecimento que vem perturbar as tranquilas águas do Ser, mas sim como um sintoma do próprio Ser. À semelhança de Lévinas, Fanon insinuou que o próprio Ser pode conter em si um lado mau e que o próprio mal pode ser produto do excesso do Ser. ${ }^{16}$ Fanon estabeleceu esta conexão prestando atenção aos processos duradouros (colonialidade) que fazem as comunidades colonizadas sentirem-se encurraladas num mundo em que, às vezes, até Deus parece ser um inimigo (Jones, 1998).

Lévinas propôs a ideia do lado mau do Ser, mas não o relacionou com a colonialidade.

Qual a estrutura desse ser puro? Será a universalidade que Aristóteles lhe confere? Será o contexto e o limite das nossas preocupações como pretendem certos filósofos

${ }_{16}$ Desenvolvi o tema dos limites e do excesso do Ser em relação ao mal no posfácio da minha tese de doutoramento (ver Maldonado-Torres, 2001). 
modernos? Não será, pelo contrário, senão a marca de uma certa civilização instalada no facto consumado do ser e incapaz de dele sair (escapar, evadir-se) [en sortir]? (Lévinas, 2001: 64)

Para Lévinas, a doença da civilização ocidental pode ser relacionada com um tal investimento no Ser que o Ocidente se viu aprisionado por ele. É bastante curioso constatar que esta noção de aprisionamento num domínio ilimitado também aparece numa das obras mais recentes e influentes de Negri. Compare-se a concepção do problema do Ser de Lévinas com a concepção que Michael Hardt e Antonio Negri têm de império, na obra do mesmo título. Um império

caracteriza-se fundamentalmente pela ausência de fronteiras: o governo do Império não tem limites. Sobretudo, o conceito de império estabelece como princípio um regime que engloba efectivamente a totalidade do espaço ou que governa o mundo “civilizado" no seu conjunto. Nenhuma fronteira territorial circunscreve o seu reino. (Hardt e Negri, 2004: 14)

De certo modo, o Império dá uma expressão consistente à descrição que Lévinas dá do Ser. Ser e Império estão intimamente ligados na medida em que, mais do que ser limitados, são limitadores. Eles dão expressão ontológica e geopolítica aos imperativos da expansão, do poder e do controlo.

Distinta da tematização inicial do Ser por Heidegger, a associação entre ontologia e formações imperiais põe em destaque a relevância do espaço para a ontologia. Contudo, o ilimitado espaço do Ser dificilmente admite diferenciações coloniais, o que torna impossível justificar o carácter selectivo da violência imperial/ontológica no mundo moderno e pós-moderno. Esta é uma das dificuldades da concepção de Império proposta por Hardt e Negri. Um dos traços característicos da proposta destes dois autores é o facto de o Império ser, de algum modo, um não-lugar. Segundo eles,

este espaço estriado da modernidade construiu lugares continuamente implicados e fundados num jogo dialéctico com os respectivos lados de fora. O espaço da soberania imperial, pelo contrário, é liso e sem estrias. Dir-se-ia livre das divisões binárias e da estriação das fronteiras modernas, mas é, na realidade, cruzado por tantas linhas de fractura que acaba por ter o aspecto de um espaço contínuo e uniforme. Neste sentido, a crise da modernidade, claramente definida, cede lugar a uma omnicrise do mundo imperial. Neste espaço liso do Império não há um lugar do poder, que está ao mesmo tempo em toda a parte e em nenhuma. O império é uma ou-topia, ou seja, na verdade, um não-lugar. (Hardt e Negri, 2004: 215) 
Se juntarmos Lévinas a esta concepção de Império, poderá parecer que o Ser cumpre o seu destino imperial na formação do não-lugar que é o Império. Mas aqui, uma vez mais, a concepção de ser que surge nas obras de pensadores enraizados no Ocidente diverge daquela que emerge com pensadores que têm sobretudo consideração o modo como diferentes sujeitos, com diferentes histórias e memórias, vivenciam a modernidade e como respondem aos legados esta no mundo contemporâneo. Teorizando na tradição de W.E.B. Du Bois, no final do século que este autor considerava ser aquele que iria confrontar-se drasticamente com o problema da linha divisória da cor, Sylvia Wynter argumenta que essa divisória não é um problema apenas do século XX, mas da própria modernidade, o que inclui as suas expressões globais mais recentes. Wynter diz que

Em lado nenhum mais vincadas [hoje] do que na situação ainda subordinada e de pobreza generalizada dos descendentes dos idólatras/ Outros Humanos, sejam eles indígenas ou de descendência ex-escrava africana ou afro-mestiça, estas desigualdades expressam-se vivamente na ilógica do actual rácio de 20/80 da distribuição global dos recursos mundiais. Este rácio, como Du Bois também anteviu, teve e tem uma correlação causal com a questão da linha divisória da cor enquanto problema maior do século XX. (Wynter, 1995: 40)

Hardt e Negri, ao contrário de Wynter, limitam a análise de Du Bois ao século XX e defendem que "[o racismo imperial], pelo contrário, tendo talvez por horizonte o século XXI, assenta no jogo das diferenças e na gestão das microconflitualidades dentro de um domínio em expansão permanente". (Hardt e Negri, 2004: 220). A questão óbvia, aqui, reside em saber se a crescente desigualdade dos recursos mundiais, uma desigualdade que parece seguir, a vários títulos, um horizonte de significação particularmente moderno no que diz respeito a quem é humano e a quem não o é totalmente, poderá ser explicada por esta ênfase no "jogo de diferenças" e na "gestão das microconflitualidades".

Seguindo o exemplo de Du Bois e de Wynter, gostaria de sugerir que, na perspectiva dos grupos da modernidade reiteradamente racializados, sobretudo de povos indígenas e pessoas de descendência ex-escrava africana ou afro-mestiça, mas também de judeus e muçulmanos, um conceito de Ser assente na premissa daquilo a que normalmente se chama dialéctica da modernidade e da nação, bem como a sua suposta superação através do emergir da soberania imperial ou Império, passa ao lado do carácter não dialéctico da condenação. Ou seja, e resumindo, aquilo que para muitos são mudanças, para aqueles a quem Frantz Fanon chamou os condenados da terra mais 
parece ser a reencenação perversa de uma lógica que durante muito tempo funcionou contra eles. O espaço, para eles, nunca se torna liso, e o preconceito para com eles não pode ser compreendido através do "jogo de diferenças" nem da "gestão das microconflitualidades". Embora revele importantes dinâmicas na estrutura da soberania do mundo pós-moderno, o não-espaço do Império também pode servir um propósito ideológico, na medida em que esconde da vista a colonialidade ou a moderna lógica da condenação.

A colonialidade faz referência à raça e, consequentemente, ao espaço e à experiência. Os espaços pós-modernos podem ser definidos de uma forma pós-colonial, isto é, para além das restrições da relação entre império e colónias, mas isso não significa que, quer a raça, quer a colonialidade se tenham visto o seu poder reduzido. Sendo verdade que, até certo ponto, poderia existir um Império sem colónias, não existe Império sem raça ou colonialidade. O Império (se é que existe) opera dentro da lógica global ou da marca d'água da raça e colonialidade. É por isso que os muros e as fronteiras do Ocidente continuam a reforçar-se, com tanta facilidade, em tantos locais-chave do mundo moderno; também é por isso que os EUA são capazes de se referir explicitamente a alguns países como sendo malévolos e que, por exemplo, assistimos actualmente, em países como a França, a uma caça às bruxas que persegue muçulmanos críticos da nova direita. ${ }^{17}$ Passarei a desenvolver alguns desses aspectos antes da conclusão do presente artigo. O que quero deixar claro aqui é que esta concepção de espaço convida à reflexão não apenas sobre o Ser, mas, mais concretamente, sobre a sua faceta colonial, aquela que faz com que alguns seres humanos sintam que o mundo é uma espécie de inferno do qual não é possível escapar.

A colonialidade do Ser sugere que o Ser, de certa maneira, contraria a nossa própria existência. Lévinas, um indivíduo racializado e perseguido, teve a percepção desta realidade. O Ser não era algo que lhe abrisse o reino da significação, mas algo que parecia torná-lo alvo da aniquilação. É esta experiência racial que, em parte, explica como aquilo que para Nietzsche, filho de um pastor protestante alemão, assumia a expressão de uma mistificação ascética, para Lévinas, judeu da Lituânia, se afigura claramente como maldade e violência. Ele vivencia um aspecto diferente das modalidades ocidentais de ser. Porém, embora Lévinas comece a afastar-se radicalmente

\footnotetext{
${ }_{17} \mathrm{O}$ caso de Tariq Ramadan é importante aqui. Ver, entre outros também recentes, artigos relevantes em Le Monde (23 de Dezembro de 2003) e E. Sciolino, 'A Muslim Scholar Raises Hackles in France', New York Times, 16 de Novembro de 2003. Entre as obras de Ramadan, ver Ramadan, 1999 e 2004. Entre os seus críticos, contam-se "nouveaux philosophes" como Bernard-Henri Lévy, que, em vasta medida, reproduzem alguns dos aspectos mais problemáticos do projecto de outros pensadores franceses judaicos, como é o caso de Lévinas.
} 
das concepções europeias do Ser, o seu comprometimento com o Ocidente enquanto projecto de civilização e formação epistémica impede-o, em última análise, de expressar uma visão do ser que explique a lógica da condenação. É por isso que a sua visão do Ser parece desabar tão facilmente, dando lugar a uma concepção como a de Hardt e Negri.

Os limites da explicação de Ser de Lévinas vêm ao de cima, se ela for comparada com a de figuras que também responderam criticamente aos ideais ocidentais a partir da perspectiva de subjectividades racializadas. $\mathrm{Na}$ sua obra clássica Is God a White Racist? (Será Deus um branco racista?), William Jones defende que o sofrimento do povo negro legitima que se introduza a questão do racismo divino. Ou seja, tal enormidade, quer seja não-catastrófica, quer seja natural, e, acima de tudo, a deficiente distribuição do sofrimento deveria, por si só, levar-nos a perguntar se Deus, ele próprio - ou ela própria - não será um(a) Branco(a) Racista (Jones, 1998). A sensação de estar encurralado num paradigma de violência que já dura há séculos e a experiência de ver o modo como as mudanças para todos estão longe de se traduzir em mudanças para a pessoa individual e para a sua comunidade conduzem, naturalmente, à questão de saber se o ser é intrinsecamente colonizador ou se Deus é racista. É claro que existe uma importante diferença entre uma e outra coisa. Embora Deus seja capaz de, graças à sua capacidade de agência e autonomia, seleccionar o objecto do seu divino preconceito, não fica claro como é que a violência do Ser enquanto tal se pode apontar para um determinado grupo ou população. Em suma, embora a violência ontológica possa dar origem a um Império, quer dizer, a uma forma transnacional e impessoal de soberania, não se torna claro como se encontra ligada ao colonialismo e ao racismo. O que não encontramos aqui é uma explanação do carácter preferencial da violência; pois quando o Ser é opressivo, não o é igualmente para todos. Poderemos, portanto, falar de uma violência ontológica generalizada, mas não, necessariamente, de uma colonialidade do Ser.

A colonialidade do Ser terá de se referir não apenas a um acontecimento de violência originário, mas também ao desenrolar da história moderna em termos de uma lógica da colonialidade. ${ }^{18}$ Proponho que, para concretizar isto, teremos de seguir Heidegger, relacionando o Ser com a historicidade e a tradição - um movimento que sustenta uma grande parte da hermenêutica de Gadamer. A diferença em relação a Heidegger e Gadamer seria que, em vez da historicidade e tradição, o que melhor explicaria o desenrolar do Ser e a colonialidade do Ser seria a diferença colonial e a lógica da colonia-

${ }_{18}$ Devo a Walter Mignolo o conceito de lógica da colonialidade. 
lidade. Por outras palavras, considero que o Ser representa, para a história e a tradição, o mesmo que a colonialidade do Ser representa para a colonialidade do poder e para a diferença colonial. A colonialidade do Ser refere-se ao processo pelo qual o senso comum e a tradição são marcados por dinâmicas de poder de carácter preferencial: discriminam pessoas e tomam por alvo determinadas comunidades. O carácter preferencial da violência pode traduzir-se na colonialidade do poder, que liga o racismo, a exploração capitalista, o controlo sobre o sexo e o monopólio do saber, relacionando-os com a história colonial moderna (Quijano, 2000). O que proponho, enfim, é o seguinte: para definir e desvelar a colonialidade do ser poderemos seguir o trajecto de Heidegger e Gadamer, mas apenas - como fez também, em parte, Lévinas - transgredindo as suas fronteiras e as suas perspectivas eurocentradas. Teremos de introduzir ideias nascidas da experiência da colonização e da perseguição de diferentes subjectividades. A colonialidade do Ser poderá vir a ser uma forma possível de teorizar as raízes essenciais das patologias do poder imperial e da persistência da colonialidade. Ela permitirá estabelecer relações entre Ser, espaço e história, que se encontram ausentes das explicações heideggerianas e que também se perderão se se associar o Ser ao Império. Além disso, a colonialidade do Ser introduzirá a questão do ser-colonizado ou do condenado, o qual se perfilará como uma alternativa não só ao Dasein de Heidegger, como também ao moderno conceito de "povo" e ao conceito de "multidão" de Hardt e Negri. ${ }^{19}$ Apesar de não me ser possível aprofundar aqui estas ideias, é minha intenção descobrir por que razão Lévinas, que fez uma reflexão crítica sobre a ontologia com tanta originalidade e sofisticação, não percorreu o caminho que acabo de mencionar. ${ }^{20}$ Isto, por sua vez, levar-me-á a explorar a questão das conexões entre a busca de raízes étnicas (em Atenas) e a busca de raízes religiosas (em Jerusalém).

\section{Entre Nova lorque e Bagdad, ou a cegueira perante a condenação: Cristianismo, Judaísmo e a renovada busca das raízes}

Gostaria de iniciar esta secção com a questão do porquê de Lévinas não sentir que tivesse de explicar o carácter complexo, mas selectivo da violência, tão visível no colonialismo. Pelo menos de uma certa forma, a resposta a esta pergunta diz-nos que, não obstante Lévinas ter fortes suspeitas em

\footnotetext{
${ }^{19}$ Hardt e Negri desenvolvem a comparação entre as ideias de "povo" e "multidão" em Hardt e Negri, 2003.

${ }^{20}$ Desenvolvo estas ideias em 'On the Coloniality of Being' ("Sobre a colonialidade do ser"), uma palestra inédita que proferi no Centro para os Estudos Globais nas Humanidades, na Universidade de Duke, a 5 de Novembro de 2003.
} 
relação à bondade europeia, especialmente quando esta assentava exclusivamente em termos de inspiração liberal, não lhe interessavam os legados dos impérios europeus liberais e não-liberais nem deles tinha sequer consciência, e muito menos ainda da lógica da condenação que subjaz à modernidade. Ao passar em revista muitos dos seus escritos, torna-se claro que a crítica que Lévinas dirige à ontologia se baseia mais na sua experiência enquanto judeu europeu e no seu interesse em redimir o valor epistémico do judaísmo, do que nas conexões entre a sua posição e a dos povos colonizados interessados em projectos de descolonização e na formulação de cosmopolitismos descoloniais. Ou seja, o projecto intelectual de Lévinas está fortemente circunscrito pelo interesse em mostrar a pertinência das fontes judaicas para o pensamento ocidental e em apresentar provas das raízes ontológicas do anti-semitismo. Lévinas faz isto muito bem. Porém, quando se trata de demonstrar como a civilização ocidental usa de parcialidade contra os vários outros colonizados, Lévinas retorque simplesmente defendendo a ideia de que esses outros são vítima do mesmo anti-semitismo, do mesmo ódio pelo Outro homem. ${ }^{21}$ Para Lévinas, o Judeu denota quer a possibilidade de transformação epistémica, quer essa categoria mais generalizada que é a opressão. Todos os colonizados são, no seu sofrimento e marginalização, judeus. Sendo assim, por que razão a sociedade ocidental persegue os judeus? A perseguição encontra-se ligada à religião e à possibilidade de transformação epistémica. O que o Judeu vem introduzir de novo na cultura ocidental é aquilo que, para Lévinas, o torna único enquanto judeu, isto é, uma ética de responsabilidade suprema para com os outros seres humanos. O Judeu foi eleito por Deus para servir os outros e para, assim, lhes lembrar a responsabilidade dele para com os outros (Lévinas, 1990). Para Lévinas, o problema da civilização ocidental não reside no esquecimento do Ser, mas sim na perseguição aos Judeus. Perseguição que é natural num contexto em que as exigências de preservação e conservação ofuscam as exigências da ética e da responsabilidade radical para com o outro, ou pelo menos é esse o entendimento de Lévinas.

Concluindo, portanto, é um facto que Lévinas aborda a questão da selectividade da dominação, mas a explicação que oferece é seriamente limitada pela sua visão filosófica e religiosa, bem como pela sua preocupação mais ou menos exclusiva com a identidade dos Judeus, em especial os Judeus europeus e os de Israel. ${ }^{22}$ Infelizmente, a filiação étnica e o comprometi-

\footnotetext{
${ }^{21}$ Ver dedicatória em Lévinas, 1998.

22 Encontram-se alternativas a estas tendências exclusivistas nos projectos respeitantes a individualidades judaicas provenientes das Caraíbas, América Latina e EUA, como Jane Anna Gordon, Lewis Gordon e Santiago Slabodsky.
} 
mento religioso tomam o lugar da análise histórico-social rigorosa. Há um grande investimento na ideia do Ocidente que cega Lévinas para as várias formas de opressão, para as experiências de cariz colonial, para os legados imperiais, para os locais de conflito e para a mudança epistémica. É verdade que tal cegueira não é exclusiva de Lévinas. Em minha opinião, há que entendê-la, antes de mais, como um traço constitutivo da modernidade e da pós-modernidade enquanto tal. Por este motivo, não surpreende ver uma lógica semelhante noutros textos sobre os quais já me detive, como sejam Job de Negri e Império de Hardt e Negri.

A procura de respostas por parte de Negri, no Livro de Job, e a sua particular interpretação do texto, também mostram como um comprometimento com o Ocidente, neste caso através do cristianismo ocidental, pode cegar um intelectual no que diz respeito à lógica da colonialidade. Na introdução de Job, Negri escreve:

Uma vez que nós éramos como Job, que lutou contra os poderes que escravizam e dominam o mundo e contra a miséria que os mais fortes e cruéis criam, houve a necessidade de insistir numa relação corpo a corpo, semelhante àquela que Job tinha com Deus.

Deste ponto de vista, é fácil compreender a importância da crença dos padres cristãos da antiguidade, que viam em Job uma prefiguração de Cristo: tal como nós, ele atravessou o deserto para que pudesse alcançar um nível de vida mais elevado, uma redenção absolutamente materialista, que corresponde à felicidade de revolucionar o mundo. (Negri, 2003: 20; sublinhados meus)

O que este excerto tem de peculiar é a forma como Negri faz substituir, com um vago "nós", sujeitos que se encontram em posições inescapáveis de sofrimento semelhantes à de Job. Este gesto contrasta fortemente com outras leituras de Job que vêem nas respostas dadas por este a Deus uma descoberta da inocência do sofrimento dos outros e um comprometimento com a condição precária daqueles que parecem ser condenados por uma situação que nem criaram nem pediram (Gutiérrez, 1987; Nemo e Lévinas, 1998). No debate crítico em que se envolveu com Hardt e Negri, Timothy Brenan também chamou a atenção para a estranheza e a peculiaridade da substituição deste vago "nós" de uma certa esquerda europeia, por sujeitos em múltiplas posições de subordinação:

Cada vez que os novos italianos falam de trabalhadores, vêem uma imagem de si próprios, ainda que essa imagem, necessariamente, se esbata em constructos que vão para além dos mexicanos à jorna, dos moços da entrega de comida rápida, das 
secretárias, domésticas e mecânicos de automóveis. Esse tipo de especificidade mancha a aura da 'multidão' - um termo com laivos do Novo Testamento, que os autores adoptam para escapar ao telos culposo da classe operária. Mas o termo multidão trai uma teleologia inversa, por assim dizer, uma etiologia que é religiosa na forma: a designada 'multitude fidelium' (429). Apesar de quase ter passado despercebida, há que, neste contexto, mencionar a formação política e intelectual de Negri no radicalismo católico da década de 50 do século XX italiano. A maior parte dos autores de recensões críticas tem tido muito pouco a dizer acerca da inspiração inicial de Negri no radicalismo católico - a qual não deixa de ter uma certa relação com a harmonia universal das suas concepções mais recentes. (Brennan, 2003: 364-365)

Tal como em Lévinas, existe na obra de Hardt e Negri uma "teologia velada" que toma o lugar de uma cuidadosa elucidação das variedades de lutas e condições existenciais de sujeitos com diferentes legados imperiais, diferentes cosmologias e diferentes aspirações à transformação do ego e do mundo. O caso de Lévinas é o mais interessante, pois, embora desafie os constrangimentos do cânone filosófico ocidental e reactive, com isso, as lições do Talmude e da Bíblia hebraica de uma forma crítica, mesmo assim acaba por não chegar a observar a colonialidade do saber em funcionamento. Portanto, não chega a associar, de uma forma significativa, a sua luta à de outros sujeitos racializados da modernidade. Trata-se de sujeitos cujos corpos e contributos epistémicos ficaram marcados, como Lévinas, pelo mal do racismo. Os estudiosos que se especializam em Lévinas normalmente centram-se nos seus contributos para a viragem linguística, lendo-o em diálogo com Heidegger, Derrida e outras figuras da filosofia continental. Ao abordarem o trabalho de Lévinas apenas no que diz respeito à genealogia e disciplina da filosofia ocidental, tendem a deixar as questões da espacialidade e da colonialidade totalmente de fora das suas reflexões. Tendem, assim, a repetir o mesmo tipo de problemas que encontramos na obra de Lévinas. A espacialidade, a colonialidade e a luta pela diversidade epistémica também são deixadas de lado na conceptualização que Hardt e Negri fazem do Império e na formação da "multidão". As explicações como as de Lévinas e as de Hardt e Negri são incapazes de reconhecer o imperativo da pluriversalidade ética e epistémica no mundo. Um dos motivos para que assim seja é que as metanarrativas do judaísmo e do cristianismo são fortemente privilegiadas nos escritos destes autores. Enquanto Lévinas identifica o racismo com o anti-semitismo, Hardt e Negri (na verdade, muito mais Negri do que Hardt) conseguem apenas ver S. Francisco de Assis como o exemplo mais adequado de um militante comunista (Hardt e Negri, 2004: 
413). De alguma forma, Hardt e Negri querem fazer justiça a Roma (numa versão [católica] romana da utopia comunista), enquanto outros insistiram na Floresta Negra e outros ainda em Atenas e Jerusalém.

Voltar a fazer entroncar a esperança comunista no cristianismo europeu tornou-se muito importante para a esquerda europeia após a queda da União Soviética. Perante a incapacidade de encontrar um lar na União Soviética ou no partido comunista tradicional, não se perfilavam muitas opções para manter vivo o projecto comunista. Houve, por isso, a necessidade de reconciliar a esquerda marxista europeia com a Europa e com o cristianismo ocidental. Quando essa necessidade se tornou instante, a própria ideia de Europa passara a ser contestada por estudiosos que, retomando a visão de Fanon sobre as raízes da Europa, se voltaram para uma crítica severa do projecto da civilização europeia. Como alguém que, desesperado, andasse em busca das suas raízes, a esquerda tem mostrado tendência para se tornar cada vez mais reaccionária, a ponto de adoptar a ortodoxia como divisa da crítica. ${ }^{23} \mathrm{O}$ marxista lacaniano Slavoj Žižeck representa a mais alta expressão da angústia das raízes que caracterizou o projecto esquerdista na Europa e também nos EUA.24 A sua busca de raízes não é totalmente diferente da de Heidegger. À semelhança deste, na obra de Žižeck está presente uma crítica extrema à modernidade ocidental e, simultaneamente, uma igual tentativa de salvar o Ocidente. A diferença reside no facto de Heidegger se ter voltado para o fascismo e o germanocentrismo, enquanto Žižeck recupera o marxismo, o eurocentrismo e uma versão ortodoxa do cristianismo ocidental (Žižeck, 2000, 1998). Esta diferença, contudo, só reforça a maior afinidade entre Heidegger e Žižeck, e que é o seu racismo epistémico. Isto porque, se Heidegger não conseguia pensar uma filosofia genuína fora da língua alemã, Žižeck não consegue considerar o radicalismo político fora da díade marxista-cristão. Como o próprio afirma em The Puppet and the Dwarf,

O que aqui defendo não é só que sou um materialista por inteiro e que o cerne subversivo do cristianismo também se encontra acessível a uma abordagem materia-

\footnotetext{
${ }^{23}$ Ver o capítulo 'The "Thrilling Romance of Orthodoxy"' (pp. 34-57) de Žižek 2003. Os pontos de vista de Žižeck sobre a ortodoxia estão relacionados com as suas conversas com John Milbank e outros pensadores do projecto da ortodoxia radical. Para uma visão geral do projecto da ortodoxia radical, ver Milbank et al., 1999.

${ }^{24}$ Nos EUA foi mais o patriotismo do que, propriamente, o cristianismo que serviu de alicerce aos liberalistas pragmáticos de tendência esquerdizante, como Richard Rorty e Cornel West. Ver nomeadamente Rorty, 1998, e West, 1989. Faço uma análise crítica destas tendências em Maldonado-Torres, 'Toward a Critique of Continental Reason', in Companion to African-American Studies. Cambridge, MA: Blackwell (no prelo).
} 
lista; a minha tese é muito mais forte: este cerne só é acessível a uma abordagem materialista - e vice-versa: para se ser um verdadeiro materialista dialéctico, deve-se passar pela experiência cristã. ${ }^{25}$

O conservadorismo de Žižeck é radical e, por isso, desafia a complacência tanto de conservadores como de não-conservadores. O radicalismo, porém, não esconde a dimensão do racismo epistémico, tal como as sugestivas análises do problema da tecnologia e do niilismo por parte de Heidegger não a escondiam. Este racismo é evidente no passo acima transcrito. Uma vez que, na obra de Žižeck, nunca aflora a ideia de que poderiam existir opções políticas verdadeiramente radicais para além dos horizontes do materialismo dialéctico, depreende-se que o cristianismo é a única fonte de verdadeiro radicalismo. Isto explica, entre outras coisas, o modo como o autor encara o budismo. A visão de Žižeck sobre o cristianismo e a esquerda permitem-lhe aderir a uma nova forma de orientalismo que não conhece fronteiras. Depois de algumas páginas dedicadas à análise das declarações de uns quantos budistas Zen e de uma parte do Bhagavad Gita, Žižeck arroga-se autoridade suficiente para fazer a seguinte observação:

Isto significa que a Compaixão budista (ou hindu, já agora), que tudo abarca, se tem de contrapor à intolerância cristã, ao Amor violento. A atitude budista é, em última instância, uma atitude de Indiferença, de extinguir todas as paixões que procurem fixar diferenças; por seu lado, o amor cristão é uma paixão violenta que visa introduzir a Diferença, um fosso na ordem de ser, para privilegiar e elevar um qualquer objecto à custa de outros. (Žižeck, 2003: 33)

Žižeck reifica o budismo e o cristianismo e atribui-lhes lógicas intrínsecas que ajudam a fazer a distinção entre um e outro de uma forma tão fácil como a que permitiu a Heidegger fazer a distinção ente línguas filosóficas e não-filosóficas. Para Žižeck, a espiritualidade oriental é indiferente ao mundo e a sua lógica de não-distinção leva os seus seguidores a tornarem-se cúmplices dos poderes militares, se não mesmo a apoiá-los abertamente. Os monoteístas, pelo contrário, ou são tolerantes com as diferenças ou intolerantes em relação ao amor. ${ }^{26} \mathrm{~A}$ busca de raízes inibe a capacidade de examinar cuidadosamente a forma como aquilo a que chamamos religião nunca funciona no vácuo. O extremismo do racismo epistémico de Žižeck

${ }_{25}$ Žižeck, 2003: 6. Esta tese complementa ideias que Žižeck já tinha explorado em Žižeck, 1999.

26 Žižeck escreve: "[O]s verdadeiros monoteístas são tolerantes: para estes, os outros não são objecto de ódio, mas apenas pessoas que, embora não sejam iluminadas pela verdadeira crença, devem ser respeitadas, uma vez que não são intrinsecamente más" (Žižeck, 2003: 27). 
manifesta-se na medida em que ele, embora descartando a "espiritualidade oriental" devido às afinidades desta com o militarismo, mantém Hegel no seu santuário, apesar de Hegel se ter mantido um dos mais fortes apoiantes da guerra no mundo ocidental. ${ }^{27}$

Em contraste com Žižeck, que tenta fazer uma distinção entre entidades discretas a que se dá o nome de religiões ou espiritualidades, proponho que os problemas de intelectuais como Lévinas ou Negri, que investem forte nas visões religiosas, não são tanto as visões religiosas em si mas também, e talvez mais essencialmente, o seu desejo de enraizamento no Ocidente. É muito mais um ímpeto e um projecto do que uma fonte ideológico-religiosa discreta que os cega em relação ao lado mais negro da modernidade. As referências à ética como filosofia primeira ou à experiência nómada não escondem as tendências tautológicas que levam muitos pensadores críticos a permanecer dentro dos rígidos limites do cânone ocidental. É certo que o problema do cristianismo e, até certo ponto, do judaísmo é que ajudaram a definir o Ocidente, estando, por isso, implicados nas suas corruptas raízes. Esta consciência não deveria conduzir necessariamente ao derrotismo ou ao desespero, mas antes a um sentido de responsabilidade acrescida que ajude a trazer ao de cima aquilo que o projecto da modernidade europeia tornou invisível na Europa e em todo o lado. Um dos elementos mais óbvios que estão ausentes nas suas reflexões é a outra face menos proeminente do Ocidente e do monoteísmo: o Islão e os muçulmanos.

São várias as razões para aqui introduzir o tema do Islão e dos povos muçulmanos. Antes de mais porque, hoje em dia, qualquer referência à natureza da violência selectiva por parte das potências imperiais ou mesmo do Império torna obrigatório que pelo menos se lhes faça menção. Isto não é novidade, mas está a tornar-se mais notório nos anos do período pós-Guerra Fria. Ora, se é óbvio o porquê de não ser correcto subsumir os muçulmanos na ideia geral de multidão (hoje, os muçulmanos seriam como a multidão moribunda, a multidão visada no pós-Guerra Fria), por que haveríamos de esperar que Lévinas mencionasse os muçulmanos ou pensasse sobre a sua condição? A primeira resposta a esta pergunta é o facto de Lévinas ter vivido não só no tempo do Holocausto, como também no tempo da cruel e sangrenta guerra da Argélia, que culminou na morte de muitos milhares de muçulmanos. A segunda é que o Estado de Israel manteve, desde os seus primórdios, uma espécie de relação imperial com os palesti-

${ }^{27}$ O duplo critério de Žižeck no que diz respeito à sua crítica do "Oriente" e o tratamento macio que dá a figuras como Hegel tornam-se claras em reflexões sobre o Budismo Zen em The Puppet and the Dwarf e na defesa que faz de Hegel (em Žižeck, 2002). Ver também o diálogo crítico que William D. Hart manteve com Žižeck, em Hart, 2002. Ver ainda a réplica de Hart em Hart, 2003. 
nianos, que são, na maioria, muçulmanos. Actualmente morrem três palestinianos por cada israelita. A terceira razão dá mais que pensar. O que Lévinas não menciona, mas Primo Levi não esquece, é que Muselmann, Muselmänner ou muçulmano eram termos "que os prisioneiros dos campos de concentração nazis atribuíam a uma certa categoria de judeus desses campos que estavam prontos para morrer". Primo Levi escreve:

\begin{abstract}
Mas com os Muselmänner, os homens em decadência, nem vale a pena falar [...]. Vale ainda menos a pena fazer amizade com eles, porque não têm conhecidos de monta no campo, não ganham rações extra [...] daqui a umas semanas, não irá restar nada deles, senão um punhado de cinzas num terreno aqui perto e um número riscado numa lista. Apesar de engolidos e varridos juntamente com o resto pela incontável multidão dos seus semelhantes, eles sofrem e arrastam-se numa solidão íntima e opaca, e é na solidão que morrem ou desaparecem, sem deixar vestígio na memória de ninguém. (Levi, 1986: 89)
\end{abstract}

Os Musselmänner são "aqueles que não têm história, que descem a encosta em direcção ao fundo, como riachos que correm para o mar" (Levi, 1886: 90). De facto, Levi é mais perturbador quando diz tratar-se de "não-homens que marcham e trabalham em silêncio, a divina centelha extinta dentro deles, já demasiado vazios para sofrerem realmente. Hesita-se em dizer que estão vivos, hesita-se em chamar morte à morte deles, perante a qual eles não têm medo, pois encontram-se demasiado cansados para entender" (Levi, 1886: 90). Como afirma Ebrahim Moosa, estudioso do Islão Medieval e da Lei Islâmica, na esteira das perspectivas de Levi, neste contexto o significado de muçulmano ganha a conotação de "os fracos, os incapazes, os condenados à selecção, os verdadeiros condenados da história". 28

A diabolização de indivíduos muçulmanos não é resultado exclusivo das iniciativas imperiais europeias do século XIX. O esquecimento dos contributos epistémicos do Islão e a sua exclusão enquanto fonte relevante do Ocidente vai muito além do judaísmo de Lévinas, do contexto católico romano de Negri ou da ortodoxia de Žižeck. Se Mignolo está certo quando afirma que o imaginário do mundo colonial/moderno "surgiu no processo de estabelecimento de diferenças coloniais na fronteira sul do Mediterrâneo (com o mundo árabe) e na fronteira ocidental do Atlântico (com os ameríndios)", então, estes traços podem muito bem fazer parte integrante da própria ideia de Ocidente moderno (Mignolo, 2002: 466). Eles

${ }_{28}$ Comunicação por correio electrónico de 2 de Dezembro de 2003. 
definiram e continuam a definir o horizonte da modernidade e, com ele, legitimam o trabalho intelectual, a definição das políticas e o senso comum. Isto torna-se, hoje, patente na dinâmica geopolítica, agora que o mundo ocidental (os EUA e a Europa) está uma vez mais em conflito com o Médio Oriente. A "guerra contra o terror" também gerou dinâmicas dentro do próprio Ocidente, que parecem corroborar a preocupação de Heidegger quanto à "ameaça" que o americanismo dos EUA representa para o mundo europeu.

Actualmente, tal como aconteceu na Europa do século XVI, o império emergente está a refazer os limites e as fronteiras que irão definir a nova ordem imperial. À semelhança da própria Europa, o novo império ergue-se "no processo de estabelecimento de diferenças coloniais na fronteira sul do Mediterrâneo [e Médio Oriente] (com o mundo árabe) e na fronteira [sud]oeste com o Atlântico". O facto de a reafirmação e a reformulação destas diferenças romperem, de algum modo, com o modelo político da relação entre império e colónia não lhes reduz o significado nem o poder. A lógica da colonialidade ajudou não só a interpretar os ataques terroristas como actos de guerra, mas também a conceder a um líder político a autoridade moral para traçar no mapa um "eixo do mal". $\mathrm{O}$ ataque à cidade do Império (ou cidade do Empire State) levou à criação do Homeland Security Office, ou Gabinete para a Segurança da Pátria, que viria a ter na mira não só quem viaja para os EUA vindo do exterior, mas também todos os estrangeiros que, vivendo no país, sejam considerados uma ameaça à Pátria. Seguindo uma lógica semelhante àquela que fez com que os actos de terrorismo fossem considerados actos de guerra, a fronteira entre os EUA e o México foi sendo, a pouco e pouco, militarizada. ${ }^{29} \mathrm{O}$ Iraque e a fronteira entre o México e os EUA tornaram-se zonas da morte. No nosso mundo, as fronteiras surgem como mapas da morte imperiais. O discurso em torno da ideia de defesa da Pátria, com os seus ecos da querida Heimat de Heidegger, favorece geopolíticas racistas e conduz à justificação de agressões militares, que são vistas como trabalho missionário. A América tem de ser defendida dos homens maus que vêm de sítios maus. O Médio Oriente e a América Latina são os primeiros da fila, juntamente com esses outros sujeitos vindos de espaços liminares das modernidades ocidentais (africanos, negros, pessoas indígenas e, de modo geral, pessoas de cor).

\footnotetext{
${ }^{29}$ Sobre o problema de redesenhar as fronteiras da "Homeland", ver Andreas e Bierstecker (orgs.), 2003. Agradeço a José Palafox esta referência. Ver também o vídeo The New World Border ("A nova fronteira mundial”), produção e edição de Casey Peek, co-produção de Palafox (Berkeley, CA: Peek Media, 28 min.).
} 
O discurso dos EUA acerca do mal é acompanhado por uma oração pela Pátria ("Deus abençoe a América"). O americanismo dos EUA funda a lógica da colonialidade na velha e tradicional onto-teologia que atribui a Deus uma função primordial, o poder sobre o bem e o mal. Desta perspectiva, compreende-se o receio de Heidegger em relação aos EUA. Enquanto o seu germanocentrismo é ontológico e ancora a Europa precisamente no seu centro, a metafísica da "US Homeland" - a Pátria dos EU - representa um retrocesso à onto-teologia e um reposicionamento do coração do Ocidente, da Europa para a América. É a partir deste centro reposicionado do Ocidente, que estão a produzir-se novos desenhos globais. O Sonho Americano, tal como é actualmente adoptado pelo Estado, expressa-se no desejo de alcançar a pax americana global, na qual os ideais dos EUA no que respeita a socialidade, governação e vida em geral, se tornam ideais reguladores para as pessoas de todo o mundo. O Islão, reconhecido como uma "religião da paz", será aceitável na medida em que se assemelhar ao tipo de cristianismo praticado pelos habitantes dos EUA. O multiculturalismo esconde, assim, um multi-racismo mais profundo que apenas reconhece o direito à diferença quando as pessoas estão bem domesticadas pelo capitalismo, pela economia de mercado e pelos ideais liberais de liberdade e igualdade. A política (tanto externa como interna) segue os contornos de uma divisão entre a bem-aventurança e o mal, o lugar de Deus na terra (a civilização ocidental alcançou-o em solo americano) e os lugares do mal. É esta a nova face da lógica da colonialidade; uma face que, como Heidegger temia, não iria deixar a Europa intacta.

Tal como discuti anteriormente, a ideia de Europa surgiu não só da produção de diferenças coloniais, mas também, como mostra Mignolo, através das diferenças imperiais entre a Europa do Norte e do Sul. O germanocentrismo de Heidegger e a metafísica da Mitteleuropa foram o reflexo de um projecto político que tentou reconstituir diferenças imperiais. Hitler mostrou, de forma bastante clara, como as sociedades com um passado imperial reagem à sua marginalização. Respondeu de forma vigorosa, tentando redesenhar as diferenças imperiais a favor da Alemanha. Heidegger foi um dos intelectuais mais sofisticados de quantos procuraram promover esta causa, formulando um projecto semelhante a nível epistémico. Quando se pronunciava publicamente em França ou Itália, Heidegger sublinhava a necessidade de uma unidade europeia para fazer frente à ameaça asiática e americana. A Europa encontrava-se entre a Ásia e a América, da mesma forma que a Alemanha se encontrava no meio da Europa. $\mathrm{O}$ apelo à defesa da Europa seguia a mesma lógica do seu germanocentrismo. 
Hoje já não existe uma ameaça asiática - ou melhor, talvez agora o rosto dessa ameaça não seja soviético, mas sim do Médio Oriente. A pouco e pouco, à medida que os EUA se vão afirmando como único hegemon a nível mundial, o pesadelo de Heidegger começa a tornar-se realidade. A Europa começa a esbater-se na sombra da irrelevância. Em vez de alcançar a salvação através de uma associação íntima com uma Alemanha forte, a Europa, durante tanto tempo vista por muitos como o farol da civilização ocidental e o apogeu da racionalidade humana, perde a sua antiga e invejável relevância geopolítica. Uma "coligação da boa-vontade" formada ad hoc (ou, como alguns the chamaram, uma coligação da boa-facturação) provou ser suficiente para ganhar a autoridade moral e política artificial de que os EUA precisam para levar por diante as suas incursões imperiais. O Sul da Europa, em especial Portugal e a Espanha, puseram-se ao lado dos EUA. Este passo contribui para fazer frente à lógica das diferenças imperiais intrínsecas ao continente europeu que tornaram a Europa meridional irrelevante em termos geopolíticos ao longo dos últimos duzentos anos. Agora, aqueles países fazem parte daquilo que os EUA denominam Nova Europa, que também é composta por países da Europa de Leste que passaram a integrar a União Europeia. Os EUA estão a reforçar as diferenças coloniais (relativamente à América Latina e ao Médio Oriente) e a redesenhar as diferenças imperiais (relativamente à Europa e à União Soviética). A linha divisória que separa a Europa do Norte da Europa do Sul está também a reconstituir-se de acordo com a oposição binária entre Velha Europa e Nova Europa. A Nova Europa diz respeito aos que favorecem a incontestada potência hegemónica, enquanto a Velha Europa é o nome dado aos que, na Europa, não se resignam à sua posição na nova ordem mundial.

A reformulação da geopolítica imperial pelos EUA, que gerou uma certa instabilidade na União Europeia, explica por que razão os Europeus tiveram de reformular a sua própria metafísica da Pátria. Muito recentemente, um filósofo alemão e um francês, Jürgen Habermas e Jacques Derrida, juntaram-se para exigir uma política externa comum "a começar no núcleo da Europa”. À medida que a ameaça que Heidegger receava se foi tornando real, estes dois pensadores uniram forças numa tentativa de resistir à sua agora óbvia subalternização política. Habermas e Derrida tentam demonstrar "o que mantém a Europa unida", articulando "as raízes históricas de um perfil político" (Habermas e Derrida, 2003: 295; sublinhado meu). Se Heidegger ainda fosse vivo estaria, provavelmente, simultaneamente contente e descontente: contente porque o projecto da busca de raízes continua vivo na Europa; descontente porque a Alemanha sucumbiu perante a França e a incluiu como fazendo parte do "núcleo" da Europa. 
Passando ao lado da distinção muito marcante que o romantismo alemão estabelece entre as ideias francesas de civilização e a Kultur alemã, a figura que estabelece uma ponte entre a França e a Alemanha é o mais notável iluminista alemão, Immanuel Kant. A obra de Kant aproxima a França e a Alemanha ao mesmo tempo que promove instituições globais de autoridade que, traduzidas no presente, fariam frente à unilateralidade dos EUA. Habermas e Derrida não se interrogam sobre os laços de Kant com a mentalidade imperial da época em que viveu ou sobre a forma como o apelo de ambos "a uma política externa comum, a começar no núcleo da Europa" está totalmente ligado à problemática tradição de busca das raízes na Europa. ${ }^{30}$ Num gesto de grande condescendência, Habermas e Derrida escrevem que os Europeus "poderiam aprender, a partir da perspectiva dos derrotados, a perceberem-se a si próprios no papel dúbio dos vitoriosos que são chamados a responsabilizar-se pela violência de um processo de modernização brutal e desenraizador. Isto poderia apoiar a rejeição do eurocentrismo e inspirar a esperança kantiana de uma política interna global" (Habermas e Derrida, 2003: 297). Na sua referência aos "vitoriosos" que são chamados a responsabilizar-se pelo "processo desenraizador da modernidade", pareceria que Habermas e Derrida estão a pensar mais em Heidegger do que nos povos anteriormente colonizados. É também como se estivessem a responder mais às queixas dos românticos alemães, que eram muito críticos quanto ao Iluminismo, do que aos povos colonizados de todo o mundo. Eles reduzem os desafios do passado imperial da Europa ao "desenraizar causado pela modernidade", um processo do qual os Europeus, entre outros, foram vítimas. Não conseguem ver a particularidade do desafio que emerge no mundo colonial. É por isso que postulam que a resposta à marginalização da Europa está na busca de raízes no núcleo da Europa. A afirmação de Fanon é hoje tão significativa como o era no tempo em que Heidegger estava a forjar o seu projecto mítico de busca de raízes:

Durante séculos, em nome de uma pretensa aventura espiritual, [os Europeus] sufocaram quase toda a humanidade. Vejam-nos hoje oscilar entre a desintegração atómica e a desintegração espiritual [...]. A Europa adquiriu uma tal velocidade, louca e desordenada, que escapa hoje em dia a todo o condutor e a toda a razão [...]. Foi em nome do espírito, do espírito europeu, bem entendido, que a Europa justificou os seus crimes e legitimou a escravidão em que mantém quatro quintos da humanidade. Sim, o espírito europeu teve raízes singulares. (Fanon, 1975-1976: 312)

${ }^{30}$ Para análises críticas de Kant que têm em consideração alguns destes pontos, ver Coles (1997) e Eze (1997: 103-140). 
Até figuras como Habermas e Derrida se conformarem com esta afirmação, acredito que será impossível ultrapassarem o racismo epistémico que continua hoje a vigorar através dos mais diferentes meios.

Habermas e Derrida apelam quando muito a uma crítica eurocêntrica do eurocentrismo. Ao invés de desafiarem as geopolíticas racistas do conhecimento que se tornaram tão centrais no discurso ocidental, eles perpetuam-nas por outros meios. Por que não levar a sério os intelectuais muçulmanos? ${ }^{31}$ Por que não tentar compreender as reivindicações profundamente teóricas que surgiram em contextos que conheceram a colonialidade europeia? Por que não romper com o modelo do global ou do universal e promover o crescimento de um mundo diverso, do ponto de vista epistémico?32 Fanon não fez tudo isso, mas, de certa forma, estabeleceu uma marca, abaixo da qual os teóricos e intelectuais deveriam evitar descer. O seu radicalismo tinha que ver com uma crítica das raízes, inspirada na necessidade de responder aos condenados da terra. Os conceitos de colonialidade do poder, colonialidade do conhecimento e colonialidade do ser seguem o radicalismo de Fanon. Todavia, também podem tornar-se problemáticos se não derem espaço à enunciação de cosmologias não-ocidentais e à expressão de diferentes memórias culturais, políticas e sociais. A crítica radical deveria assumir formas dialógicas. Deveria também assumir a forma de um auto-questionamento e um diálogo radicais. O projecto da busca de raízes estaria, neste aspecto, subordinado ao projecto de crítica das raízes que mantêm vivas a dominante topologia do Ser e a geopolítica racista do conhecimento. A diversalidade radical implicaria um divórcio efectivo e uma crítica das raízes que inibem o diálogo e a formulação de uma geopolítica do conhecimento descolonial e não-racista. Parte do desafio consiste em pensar seriamente em Fort-de-France, Quito, La Paz, Bagdad e Argel, e não apenas em Paris, Frankfurt, Roma ou Nova Iorque, como possíveis lugares de conhecimento. Também precisamos de pensar naqueles que estão presos em posições de subordinação e que tentam entender quer os mecanismos que criam a subordinação, quer os que escondem a sua realidade da vista dos outros. No mundo, há muito para aprender com aqueles outros que a modernidade

\footnotetext{
${ }^{31}$ Merece ser assinalado que a Academia da Latinidade, de base maioritariamente europeia e latino-americana, e cujos membros incluem Cândido Mendes, Mário Soares e Gianni Vattimo, entre muitos outros, começou a centrar-se nas questões do diálogo intercultural. O grupo já se reuniu em Teerão e vai voltar a reunir-se em Alexandria, no Egipto, para trocar ideias sobre este tópico com intelectuais muçulmanos. Outros passos importantes neste sentido incluem também Buck-Morss (2003). Buck-Morss participou nos encontros da Academia da Latinidade. Esta estabeleceu, assim, uma relação interessante entre académicos europeus, latino-americanos, do Médio Oriente e dos EUA.

${ }^{32}$ Aparecem referências à diversalidade em Glissant (1998). Ver também Mignolo (2000: 26, 244, 273).
} 
tornou invisíveis. Esta ocasião deveria servir mais para examinar a nossa cumplicidade com os velhos padrões de dominação e de procura de faces invisíveis do que para procurar raízes imperiais; servir mais para uma crítica radical do que para um alinhamento ortodoxo contra os que são persistentemente considerados os bárbaros do conhecimento.

Num ensaio escrito em 1955, em resposta à tentativa de Ernst Jünger de cartografar o niilismo e as respostas a ele, Heidegger escreveu:

Certamente que é necessária uma topografia do niilismo, da forma como se processa e da sua superação. Contudo, a topografia tem de ser antecedida de uma topologia: uma discussão que localize o lugar onde o ser e o nada se reúnem na sua essência, determinando a essência do niilismo e deixando-nos, assim, identificar rumos onde surgem formas possíveis de superar o niilismo. (Heidegger, 1988: 311-12)

Através de uma análise da implícita topologia do Ser de Heidegger, que se encontra inscrita na sua geopolítica, propus que a aparente neutralidade das ideias filosóficas pode muito bem esconder uma cartografia imperial implícita que funde espaço e raça. O racismo - sob a forma de esquecimento da condenação, racismo epistémico e muitas outras formas - está mais disseminado do que frequentemente se pensa. Está inscrito na cartografia do que muitas vezes se considera ser um pensamento crítico e um trabalho filosófico consistente. Para além das justificações biológicas de racismo, ou das justificações baseadas em diferenças de cultura ou maneiras de estar, é possível encontrar em algumas tendências influentes do pensamento ocidental uma justificação ontológica e epistemológica mais subtil. As consequências são nefastas, uma vez que a fusão de espaço e raça está por trás de concepções militares e imperiais da espacialidade, que tendem a dar um novo significado à formulação clássica de Santo Agostinho acerca das cidades terrenas e divinas: a diferença entre a Cidade de Deus e a Cidade Terrena dos Homens traduz-se na divisão entre as cidades imperiais dos deuses humanos e as cidades dos condenados. Infelizmente, a busca de raízes na Europa e as geopolíticas racistas costumam andar de mãos dadas.

O projecto da busca de raízes na Europa também conduz, ou pelo menos assim o defendi neste artigo, à rejeição das relações geopolíticas mais amplas que operam na própria formação da modernidade. Frente a esta amnésia sistémica, Fanon propõe uma outra geopolítica. Enquanto Heidegger tenta encontrar raízes na terra e Lévinas alicerça a filosofia em duas cidades (Atenas e Jerusalém), Fanon abre um caminho de reflexão que encara a diferença colonial como ponto de partida para o pensamento crítico. Um diagnóstico crítico da topologia europeia do Ser e da sua geopolítica do 
conhecimento deverá, ou pelo menos foi o que tentei deixar claro aqui, tornar visível o que permaneceu invisível ou marginal até agora e desvendar como funcionam as categorias da condenação - por exemplo, o negro, o judeu e o muçulmano. Foi com este propósito que foram formulados conceitos como modernidade/colonialidade, colonialidade do poder, colonialidade do conhecimento e colonialidade do Ser. Estes são apenas alguns dos conceitos que teriam de fazer parte de uma gramática descolonial da análise crítica capaz de reconhecer a sua própria vulnerabilidade ao ficar aberta a posicionamentos críticos baseados nas experiências e memórias de povos que se confrontaram com a modernidade/o racismo sob qualquer uma das suas formas.

Tradução de

Inês Martins Ferreira

\section{Referências bibliográficas}

Andreas, Peter; Bierstecker, Thomas J. (orgs.) (2003), The Rebordering of North America: Integration and Exclusion in a New Security Context. New York: Routledge.

Ardíles, Osvaldo et al. (org.) (1973), Hacia una filosofía de la liberación latinoamericana. Buenos Aires: BONUM.

Bambach, Charles (2003), Heidegger's Roots: Nietzsche, National Socialism, and the Greeks. Ithaca, New York: Cornell University Press.

Blaut, James M. (1993), The Colonizer's Model of the World: Geographical Diffusionism and Eurocentric History. New York: The Guilford Press.

Bogues, Anthony (2003), Black Heretics, Black Prophets: Radical Political Intellectuals. New York: Routledge.

Brennan, Timothy (2003), 'The Empire's New Clothes', Critical Inquiry, 29, 364-365.

Buck-Morss, Susan (2003), Thinking Past Terror: Islamism and Critical Theory on the Left. London: Verso.

Casalla, Mario (1992), America en el pensamiento de Hegel: admiración y rechazo. Buenos Aires: Catálogos.

Césaire, Aimé (1978), Discurso sobre o colonialismo, pref. Mário de Andrade; trad. Noémia de Sousa. Lisboa: Sá da Costa.

Coles, R. (1997), Rethinking Generosity: Critical Theory and the Politics of Caritas. Ithaca, New York: Cornell University Press.

de la Riega, Agustín T. (1973), "América fuera del centro: del privilegio y de la culpa”, in Osvaldo Ardíles et al. (org.), Hacia una filosofía de la liberación latinoamericana. Buenos Aires: BONUM.

Dussel, Enrique (1995), The Invention of the Americas: Eclipse of 'the Other' and the Myth of Modernity, trad. M.D. Barber. New York: Continuum. 
Dussel, Enrique (1996), The Underside of Modernity: Apel, Ricoeur, Rorty, Taylor and the Philosophy of Liberation, trad. e org. de E. Mendieta. Atlantic Highlands, NJ: Humanities.

Eze, E.C. (1997), “The Color of Reason: the Idea of 'Race' in Kant's Anthropology”, in E.C. Eze (org.), Postcolonial African Philosophy: A Critical Reader. Cambridge, MA: Blackwell, 103-140.

Fanon, Frantz (1965), A Dying Colonialism, trad. H. Chevalier. New York: Grove Press.

Fanon, Frantz (1975), Pele negra, máscaras brancas, trad. Alexandre Pomar. Porto: Paisagem.

Fanon, Frantz (1975-1976), Os Condenados da Terra, trad. José Massamo. Lisboa: Ulmeiro.

Fanon, Frantz (1988), Toward the African Revolution: Political Essays, trad. H. Chevalier. New York: Grove Press.

Glissant, Eduard (1998), "Le divers du monde est imprevisible”, comunicação de encerramento do colóquio Beyond Dichotomies, Stanford University, Stanford, CA, 8-10 Maio.

Gutiérrez, Gustavo (1987), On Job: God-talk and the Suffering of the Innocent. Maryknoll, New York: Orbis Books.

Habermas, Jürgen (1990), O discurso filosófico da modernidade, trad. Ana Maria Bernardo [et al.], rev. científica António Marques. Lisboa: D. Quixote.

Habermas, Jürgen; Jacques Derrida (2003), "February 15, or What Binds Europeans Together: a plea for a common foreign policy, beginning in the core of Europe", Constellations, 10(3), 295.

Hardt, Michael; Negri, Antonio (2003), "Globalization and Democracy", in Stanley Aronowitz; Heather Gautney (orgs.), Implicating Empire: Globalization and Resistence in the 21st Century World Order. New York: Basic Books.

Hardt, Michael; Negri, Antonio (2004), Império, trad. Miguel Serras Pereira. Lisboa: Editora Livros do Brasil.

Hart, William D. (2002), "Slavoj Žižeck and the Imperial/Colonial Model of Religion”, Nepantla: Views from the South 3(3), 553-578.

Hart, William D. (2003), "Can a Judgement Be Read? A Response to Žižeck”, Nepantla: Views from the South 4(1), 191-194.

Hegel, Georg Wilhelm Friedrich (1991), The Philosophy Of History, trad. J. Sibree. Buffalo, New York: Prometheus Books.

Heidegger, Martin (1988), “On the Question of Being”, in W. McNeill (org.), Pathmarks. Cambridge: Cambridge University Press, 311-312.

Heidegger, Martin (1993a), “Only a God Can Save Us”: Der Spiegel interview with Martin Heidegger (1996)', in Richard Wolin (org.), The Heidegger Controversy: A Critical Reader. Cambridge, MA and London: MIT Press, 113. 
Heidegger, Martin (1993b), "Europa und die deutsche Philosophie”, in H.H. Gander (org.), Europa und die Philosophie. Frankfurt: Klostermann, 31.

Heidegger, Martin (1996a), Ser e Tempo, trad. Márcia de Sá Cavalcanti. Petrópolis: Vozes.

Heidegger, Martin (1996b), Hölderlin's Hymn 'The Ister', transl. W. McNeill. Bloomington: Indiana University Press.

Jones, William R. (1998), Is God a White Racist?: A Preamble to Black Theology. Boston: Beacon Press.

Lander, Eduardo (org.) (1993), La colonialidad del saber: Eurocentrismo y ciencias sociales. Buenos Aires: CLACSO.

Levi, Primo (1986), Survival in Auschwitz: The Nazi Assault on Humanity. New York: Touchstone Books.

Lévinas, Emmanuel (1988a), Totalidade e Infinito, trad. José Pinto Ribeiro. Lisboa: Edições 70.

Lévinas, Emmanuel (1998b), Otherwise than Being or, Beyond Essence, trad. A. Linis. Pittsburgh, PA: Duquesne University Press (tradução de Autrement qu'être ou, Au-delà de l'essence, 1974).

Lévinas, Emmanuel (1990), Nine Talmudic Readings. Bloomington: Indiana University Press.

Lévinas, Emmanuel (2001), Da Evasão; introd. e notas de Jacques Roland; trad. André Veríssimo. Lisboa: Estratégias Criativas.

Maldonado-Torres, Nelson (2001), "Thinking from the Limits of Being: Lévinas, Fanon, Dussel and the 'Cry of Ethical Revolt'”, tese de doutoramento, Brown University.

Maldonado-Torres, Nelson (no prelo), 'Secularism and Religion in the Modern/Colonial World-system: from Secular Postcoloniality to Postsecular Transmodernity', in M. Moraña; C. Jauregui; E. Dussel (orgs.), Postcoloniality at Large.

Maldonado-Torres, Nelson (no prelo), 'Toward a Critique of Continental Reason: Africana Studies and the Decolonization of Imperial Cartographies in the Americas', in L. R. Gordon; J. A. Gordon (orgs.), Companion to African-American Studies. Cambridge, MA: Blackwell.

Mignolo, Walter (2000), Local Histories/Global Designs: Coloniality, Subaltern Knowledges, and Border Thinking. Princeton, NJ: Princeton University Press.

Mignolo, Walter (2002), "José de Acosta’s Historia natural y moral de las Índias: Occidentalism, the Modern/Colonial World, and the Colonial Difference”, in José de Acosta, Natural and Moral History of the Indies, org. Jayne E. Morgan. Durham, NC: Duke University Press.

Mignolo, Walter (2003a), "Os esplendores e as misérias da 'ciência': Colonialidade, geopolítica do conhecimento e pluri-versalidade epistémica”, in Boaventura de Sousa Santos (org.), Conbecimento prudente para uma vida decente: Um discurso sobre as ciências' revistado. Porto: Edições Afrontamento. 
Mignolo, Walter (2003b), "Second Thoughts on The Darker Side of the Renaissance: Afterword to the second edition", in Darker Side of the Renaissance: Literacy, Territoriality and Colonization. Ann Arbor: The University of Michigan Press, 428-433.

Milbank, John; Pickstock, Catherine; Ward, Graham (orgs.) (1999), Radical Orthodoxy: A New Theology. London: Routledge.

Mudimbe, Valentin Y. (1988), The Invention of Africa: Gnosis, Philosophy and the Order of Knowledge. Bloomington and Indianopolis: Indiana University Press; London: James Currey.

Negri, Antonio (2003), Job: la fuerza del esclavo, trad. Bixio. Buenos Aires: Paidós.

Nemo, Philippe; Lévinas, Emmanuel (1998), Job and the Excess of Evil. Pittsburgh, PA: Duquesne University Press.

Quijano, Anibal; Wallerstein, Immanuel (1992), "Americanity as a Concept or the Americas in the Modern World-system”, International Social Science Journal 134, 549-550.

Quijano, Anibal (2000), "Coloniality of Power, Eurocentrism and Latin America", Neplanta: Views from South, 1(3), 533-580.

Quijano, Anibal (2001), "Globalización, colonialidad y democracia', in Instituto de Altos Estudios Diplomáticos 'Pedro Gual” (org.), Tendencias básicas de nuestra época: globalización y democracia. Caracas: Instituto de Altos Estudios Diplomáticos 'Pedro Gual', 25-28.

Ramadan, Tariq (1999), Muslims in France: The Way Towards Coexistence. Marksfield, Leicester: Islamic Foundation.

Ramadan, Tariq (2004), Western Muslims and the Future of Islam. Oxford: Oxford University Press.

Risser, James (1999), Heidegger toward the Turn: Essays on the Work of the 1930s. Albany: State University of New York Press.

Rorty, Richard (1998), Achieving Our Country: Leftist Thought in Twentieth-century America. Cambridge, MA: Harvard University Press.

Vallega, Alejandro (2003), Heidegger and the Issue of Space: Thinking and Exilic Grounds. University Park: Pennsylvania State University.

van der Veer, Peter (2001), Imperial Encounters: Religion and Modernity in India and Britain. Princeton, NJ: Princeton University Press.

West, Cornel (1989), The American Evasion of Philosophy: A Genealogy of Pragmatism. Madison: The University of Wisconsin Press.

Wynter, Sylvia (1995), “1942: A New World View”, in V. Lawrence Hyatt; R. Nettleford (orgs.), Race, Discourse and the Origin of the Americas: a New World View. Washington, DC: Smithsonian Institution Press.

Wynter, Sylvia (2000), “Africa, the West and the Analogy of Culture: the Cinematic Text after Man”, in J. Givanni (org.), Symbolic Narratives/African Cinema. London: British Film Institute. 
Žižeck, Slavoj (1998), “A Leftist Plea for 'Eurocentrism”, Critical Inquiry, 24.

Žižeck, Slavoj (1999), "The Politics of Truth, or Alain Badiou as Reader of Paul”, in The Ticklish Subject: The Absent Centre of Political Ontology. London: Verso, 127-170.

Žižeck, Slavoj (2000), The Fragile Absolute or, Why is the Christian Legacy Worth Fighting for?. London: Verso.

Žižeck, Slavoj (2002), “I Plead Guilty - But Where is the Judgement?”, Nepantla: Views from South, 3(3), 579-583.

Žižeck, Slavoj (2003), The Puppet and the Dwarf: The Perverse Core of Christianity. Cambridge, MA: mit Press, 34-57. 